\title{
A FRAMEWORK FOR ASSESSING ESTATE AND GIFT TAXATION
}

\author{
Louis Kaplow \\ Working Paper 7775 \\ http://www.nber.org/papers/w7775 \\ NATIONAL BUREAU OF ECONOMIC RESEARCH \\ 1050 Massachusetts Avenue \\ Cambridge, MA 02138 \\ July 2000
}

I am grateful to Gerard Brannon, William Gale, Pierre Pestieau, Richard Schmalbeck, Joel Slemrod, and Alvin Warren for comments, Yoram Keinan for research assistance, and the John M. Olin Center for Law, Economics, and Business at Harvard Law School for financial support. This paper was presented at the conference on Rethinking Estate and Gift Taxation, sponsored by the Office of Tax Policy Research, University of Michigan, and the Brookings Institution, and it is forthcoming in a conference volume. Many of the points developed here are drawn from a draft book chapter that received limited circulation in 1996 and 1997, and some were sketched in Kaplow (1998). The views expressed herein are those of the author and not necessarily those of the National Bureau of Economic Research.

(C) 2000 by Louis Kaplow. All rights reserved. Short sections of text, not to exceed two paragraphs, may be quoted without explicit permission provided that full credit, including (C) notice, is given to the source. 
A Framework for Assessing Estate and Gift Taxation

Louis Kaplow

NBER Working Paper No. 7775

July 2000

JEL No. H21, H23, H24, K34

\begin{abstract}
Whether and how estates and gifts should be taxed has long been a controversial subject, and the approach to estate and gift taxation varies among developed countries. Arguments for and against various forms of transfer taxation have focused on concerns about the distribution of income and wealth, intergenerational equity, raising revenue, savings incentives, and other economic and philosophical issues. This essay has two purposes. The first is to examine the conceptual basis for various arguments for and against the current estate and gift tax regime and proposed alternatives. The second is to integrate policy analysis of transfer taxation with that of the rest of the tax system, notably, the income tax. The analysis begins by considering how it would be optimal to tax transfers if they are viewed simply one of many forms of expenditure by donors, and then it explores how the distinctive features of gifts and bequests may alter the conclusions. The importance of different transfer motives is discussed, and the analysis is reconsidered in the light of the importance of human capital in intergenerational transfers; differences between inter vivos transfers and bequests, between gifts to individuals and gifts to charitable institutions, and among gifts to donees having varying relationships to the donor; and the possibility that transfers are not explained by maximizing behavior.
\end{abstract}

Louis Kaplow

Harvard Law School

Hauser 322

Harvard University

Cambridge, MA 02138

and NBER 


\section{Introduction}

Estate and gift taxation is a controversial subject. Some commentators have proposed extending transfer taxation to a larger segment of the population, increasing tax rates, and eliminating various means of tax avoidance. Others have favored substantial reductions or outright abolition. Moreover, the approach to estate and gift taxation varies among developed countries, most of which use an inheritance tax instead of estate and gift taxes and some of which have abolished transfer taxation. ${ }^{1}$

Two elements are necessary to develop a coherent assessment of estate and gift taxation. First, we need a sound conceptual framework that is explicit about the objectives to be served and that organizes thinking about a range of complex and conflicting effects of tax regimes. Second, we need empirical evidence, particularly concerning individuals' motives for giving and recipients' behavior in response to the receipt of gifts. Much prior work and some of the papers in this volume address the latter problem. ${ }^{2}$ The focus of the present essay, by contrast, will be on the former, for, without a framework, it is difficult to determine the policy implications of empirical findings and it is hard to establish research priorities for future investigation.

The thesis advanced here is that a framework for assessing estate and gift taxation should be developed systematically, beginning with first principles of welfare economics and standard results in optimal taxation. From that starting point, one should then ask what it is that makes bequests and inter vivos gifts distinctive. Thus, if voluntary transfers were no different from

\footnotetext{
${ }^{1}$ For prior discussions of these issues, see, for example, Aaron and Munnell (1992), Graetz (1983), Joint Economic Committee (1998), McCaffery (1994), Repetti (2000), essays in Erreygers and Vandevelde (1997), and Tax Law Review (1996). For background information on the system in the United States, see Johnson and Mikow (2000). For arguments concerning the distinct subject of wealth taxation (that is, taxing individuals' holdings of wealth rather than their transfer of wealth to others), see Tax Law Review (2000).

${ }^{2}$ See, e.g., sources cited in note $\underline{18}$ And Kopczuk and Slemrod (2000).
} 
expenditures on some ordinary good or service, the correct conceptual approach would be straightforward in the light of prior work on the economics of taxation, which has already addressed the factors bearing on differential taxation of various types of consumer expenditures. If the proper method of analysis for giving differs, therefore, it must be because of the manner in which making gifts is unlike using resources for one's own consumption. Thinking about the optimal tax treatment of transfers should, accordingly, start from benchmark understandings of how we should tax ordinary consumption and then consider modifications (perhaps substantial ones) that reflect the unique features of transfer behavior.

The foregoing approach is pursued in section 2. The discussion begins with a nontechnical review of the optimal taxation of different forms of expenditure in the standard optimal income tax framework. (It should be noted that most of the insights gleaned from optimal income tax analysis will be relevant even in a world in which the prevailing income tax is not set optimally.) Use of this framework is appropriate not only because it is the most systematic method that economists have developed for analyzing tax policy but also because, in fact, countries that make use of estate and gift taxes also have income taxes (and/or consumption taxes) in place. Hence, to analyze behavior and to assess welfare, we must take into account the combined impact of transfer taxes and income taxes. Relatedly, there is the question of how income (or consumption) taxes should treat gifts, and, one presumes, a tax on transfers administered through an income tax will have the same effect as an equivalent one imposed under the auspices of a transfer tax regime.

When such a framework is employed, the question of transfer taxation can be stated as follows: how much more or less (if at all) should we tax, at the margin, a dollar that a donor transfers to a donee compared to the situation in which the donor instead spends the dollar on 
own-consumption? $?^{3}$ Putting the question this way reinforces the need to examine the particular characteristics of gifts. The main feature to note is that the donor's act of giving — which can be viewed as a species of consumption by the donor — is simultaneously a source of income - and thus, prospectively, consumption — to the donee. (This is the case for "true gifts," those not involving some form of exchange between the donor and donee.) One consequence is that, in assessing social welfare, there will be a positive effect — a positive externality of sorts — on an individual (the donee) other than the one whose behavior is initially the subject of examination (the donor). Another important consequence is that the receipt of gifts may be expected to affect the behavior of donees in a manner that will be relevant to social welfare. Notably, the receipt of gifts will have an income effect, tending to reduce labor effort, which has a negative effect on income tax revenues - a negative externality on the public fisc.

In section 3, the inquiry is broadened by considering the range of transfer motives that underlie giving behavior. Although motives are not important in themselves in assessing social welfare, different motives suggest different forms of utility functions. And, when utility functions differ, given policies will have different effects on behavior. In addition, assessments of welfare depend on the form of individuals' utility functions. Hence, transfer motives are important in assessing transfer tax policy.

Using the framework developed in the first two sections, a number of the familiar policy considerations in the debate over estate and gift taxation are revisited in section 4. These topics include redistribution (viewed both within and between generations), raising revenue, savings, administrative and compliance costs, and concentration of wealth and power. A recurring theme

\footnotetext{
${ }^{3}$ It is also instructive to restate the question for the case of in-kind transfers. If, say, an individual buys a set of golf clubs, should the person's overall tax burden be higher or lower (and by how much) if the golf clubs are given to one's child rather than used for oneself?
} 
in this section is that many of the common ways of discussing these issues are incomplete and, sometimes, misleading, because they are not rooted in first principles of policy assessment (welfare economics) and of optimal tax theory.

A number of additional subjects will be examined briefly in section 5: the relevance of human capital, which, on one view, is by far the largest component of intergenerational transfers, yet is largely ignored in most analyses of estate and gift taxation; possible differences between inter vivos gifts and bequests; taxation of the family, recognizing that a substantial portion of all transfers are between spouses; charitable giving; and the possibility that gifts are not always the result of maximizing behavior by donors. ${ }^{4}$ Concluding remarks will be offered in section 6 .

\section{The Taxation of Transfers in an Optimal Income Tax Framework}

In this section, the individuals' utility maximization problem, with a budget constraint that reflects both income taxation and possible transfer taxation, will first be presented, followed by a statement of the social welfare maximization problem. Then, the optimality of differential taxation will be analyzed, first, in the case in which expenditures on transfers are not qualitatively different from expenditures on other forms of consumption and, second, in the case in which transfers are distinctive.

Throughout most of the discussion in this section and the rest of this essay, it will ease exposition to make a number of simplifications. ${ }^{5}$ Thus, the analysis will consider the aggregate

\footnotetext{
${ }^{4}$ Another important subject, beyond the scope of the present inquiry, concerns the question of transfer tax reform per se - that is, how one should make the transition to another transfer tax regime and whether the fact that a given tax system is currently in place bears on what sort of reform would be optimal. As an example, in the present analysis it is assumed that inheritances must come from somewhere — from donors — who in turn must have earned the funds at some point (or received them from another donor who once earned the funds, and so forth); this is relevant because such prior behavior is presumed to be subject to the same overall tax system, taken to be in place throughout time. By contrast, when new taxes are suddenly implemented (i.e., are unanticipated) it is always possible to tax some (indeed, all) existing capital without distortion; likewise, unexpected repeals will generate windfalls.

${ }^{5}$ The list in the text is hardly exhaustive. Also ignored are many other matters, including strategic behavior by donors (e.g., gifts intended to shape donees' utility functions to induce possible return gifts of care or funds in the future) and by donees (e.g., the Samaritan's dilemma, rent-seeking behavior).
} 
net taxation of transfers, not distinguishing whether the tax is part of an income or consumption tax system or a separate transfer tax regime. Inter vivos gifts and bequests will simply be referred to collectively as gifts or transfers. The analysis will often focus on a single donor and donee (although the interpretation, of course, will be that these are representative individuals) ${ }^{6}$ Although the donor and donee may have any relationship, the usual interpretation will be that of intergenerational transfers, from parent(s) to child(ren). ${ }^{7}$ Transfers will usually be taken to involve true gifts, rather than transfers that are one component of an exchange relationship. And individuals will be assumed to behave as informed, rational maximizers of their utility. Each of these assumptions, however, will be addressed to some extent in subsequent sections.

\subsection{Donors' utility maximization problem}

Consider the following simple utility maximization problem. There are two periods. In the first period, an individual chooses a level of labor effort, $\ell$, yielding before-tax income of $w \ell$. Taxes on labor income are $T(w \ell)$; that is, there is an income tax that may be nonlinear. (It also may provide for negative taxes, that is, welfare support payments.) After-tax income may be spent on consumption in period $1, c_{1}$, or deferred, earning interest at the rate $r$, until period 2. Then, remaining resources may be spent on ordinary (own) consumption, $c_{2}$, or on another good, $c_{g}$. Ultimately, $c_{g}$ will be interpreted as expenditures on gifts, but the model will also be interpreted where $c_{g}$ refers to expenditure on some other good or activity, such as playing golf. There are taxes $t_{r}$ on the return to savings and $t_{g}$ on consumption of $c_{g}$ (each of which may be negative, i.e., subsidies).

\footnotetext{
${ }^{6}$ The possibility that the donee might in turn save a gift and later give it to others, such as members of a subsequent generation, is implicitly captured by the analysis, for the subsequent gift can be treated as simply another instance of a gift involving a different donor-donee pair.

${ }^{7}$ The donor might be a representative parent and the donee a representative child. Likewise, only net transfers, in a single direction, will be considered.
} 
Thus, the individual chooses a level of labor effort and levels of each type of

consumption to maximize

$$
U\left(c_{1}, c_{2}, c_{g}, l\right)
$$

subject to the budget constraint ${ }^{8}$

$$
w \ell-T(w \ell)=c_{1}+\frac{c_{2}+\left(1+t_{g}\right) c_{g}}{1+r\left(1-t_{r}\right)}
$$

Setting $t_{g}=0$ for the moment, consider two standard interpretations of this expression. First, when $t_{r}=0$, this formulation is a standard labor income (wage) tax, which is also equivalent to a tax on lifetime consumption. Second, when $t_{r}=t$, where $t$ is the uniform marginal tax rate on labor income, this corresponds to a standard proportional income tax (here which includes investment income). ${ }^{9}$

${ }^{8}$ Such a budget constraint is sometimes written as

$$
w \ell-T(w \ell)=\left(1+t_{1}\right) c_{1}+\frac{\left(1+t_{2}\right) c_{2}+\left(1+t_{g}\right) c_{g}}{1+r}
$$

where the taxes $t_{1}, t_{2}$, and $t_{g}$ are levied on each type of consumption $c_{1}, c_{2}$, and $c_{g}$, respectively. This expression is equivalent to that in the text: $t_{1}$ is redundant: one can divide both sides by $1+t_{1}$ and restate $T(w \ell), t_{2}$, and $t_{g}$; then, one can restate the taxes on the two forms of period 2 consumption as a tax on interest earnings, $t_{r}$, and an additional tax (or subsidy, if negative) on $c_{g}$ (relative to $c_{2}$ ), further restating the other tax terms. Then, the budget constraint would be the same as that in the text.

${ }^{9}$ To allow for a nonlinear tax that combines labor and investment income, one would have to rewrite the budget constraint; the present, simpler formulation clarifies analysis of the taxation of savings and its relationship to transfer taxation. 


\subsection{Social welfare maximization problem}

Consider the following simplified formulation of the social welfare maximization problem. As in the standard optimal income tax problem, assume that there is a continuum of individuals, where their type, $w$, distributed according to the density function, $f(w)$, indicates individuals' earnings ability, which is not observed by the government. (Hence, redistributive taxation must use income as a signal, and redistribution will involve distortion of the labor/leisure choice.)

Society is assumed to choose tax schedules and rates in order to maximize a utilitarian social welfare function

$$
\int U(w) f(w) d w
$$

subject to a revenue constraint (that tax revenues equal transfer payments plus expenditures on public goods) and individuals' maximizing behavior, where individuals are assumed to take the government's policy as given and maximize their utility functions, as described in the preceding subsection.

Two simplifications, which do not fundamentally affect the analysis to follow, should be noted. First, this formulation of the social welfare function is utilitarian, though one could allow, say, for a welfare function that is strictly concave in individuals' utilities — indicating additional aversion to inequality. Second, public goods are suppressed, so the problem is stated as if taxes are purely redistributive. One could instead include public goods in individuals' utility functions, in which case the government's welfare maximization problem would involve choosing the level of public goods as well as tax schedules and rates. 


\subsection{Analysis where $\mathrm{c}_{\mathrm{g}}$ refers to expenditures on another form of ordinary consumption}

It is useful as a benchmark to begin the analysis not with gifts, but with the case in which $c_{g}$ refers simply to expenditures on some ordinary form of period 2 consumption, such as playing golf during one's retirement years. In this case, the problem can be restated as whether expenditures in the second period on golf should be taxed more or less heavily (and to what extent) than expenditures in the second period on other goods and services (e.g., dining in restaurants). The solution to this problem is familiar. See, e.g., Atkinson and Stiglitz (1976), Stiglitz (1987).

Case of weak separability. - First, assume that individuals' utility functions are weakly separable in labor (leisure), in which case they can be written as

$$
U\left(x\left(c_{1}, c_{2}, c_{g}\right), l\right)
$$

where $x$ is a subutility function. The interpretation of weak separability is that the marginal disutility of labor effort does not depend on how one allocates disposable income among different types of consumption. Another interpretation of this condition is that individuals' allocations among different types of consumption depends only on the effective prices (including taxes) of different types of consumption and on their disposable income, not on the level of labor effort required to produce their income.

Now, in this case, it is familiar that the optimum involves no differential taxes on different types of consumption. ${ }^{10}$ That is, one should set equal to zero both $t_{r}{ }^{*}$ and $t_{g}{ }^{*}$, the optimal tax (subsidy) rates on investment earnings (i.e., the deferral of consumption from period

\footnotetext{
${ }^{10}$ There are other assumptions implicit in this framework that are explored in the optimal taxation literature and will not be pursued here. Conceivably, some would have particular relevance to transfer taxation.
} 
1 to period 2) and on playing golf. The reason for this result is that differential taxes on different types of consumption expenditures cause distortions among types of consumption but do not alleviate the labor/leisure distortion. Hence, they involve a cost but produce no benefit.

Before proceeding, it is worth pausing to emphasize some of the factors that this result does not depend on. First, it does not depend on individuals" "motives" for engaging in the different types of consumption. Thus, whether individuals play golf because they like fresh air, swinging clubs, or viewing the color green (or tan or blue, as the case may be) is irrelevant. (This point is mentioned because, when interpreting $c_{g}$ as expenditures on gifts, the question of motivation is often raised; motives for giving will prove to be relevant, but only indirectly.)

Second, these results disfavoring differential taxation do not depend on the magnitude of the pertinent elasticities - of savings, in the case of $t_{r}$, and of playing golf, in the case of $t_{g}$. (And in the much discussed case of savings, the result does not depend on whether the uncompensated savings elasticity is positive, negative, or zero, either with respect to the price of period 2 consumption in general or with respect to the price of $c_{g}$ in particular.) Of course, the extent of the distortion will depend on the relevant (compensated) elasticities.

A further important observation is that it is not optimal in the present setting to impose differential taxes on different forms of consumption in order to redistribute income. For example, suppose that $c_{g}$ is a form of consumption (playing golf) that is undertaken disproportionately by the rich. Furthermore, assume that more redistribution would in principle be desirable. Does it follow that $t_{g}{ }^{*}>0$ ? No. The reason is that one can tax the rich more heavily through the income tax itself. If that tax is set optimally, attempting further redistribution indirectly necessarily lowers welfare; further indirect redistribution is less efficient than further direct redistribution because the former involves an additional consumption distortion (with no 
offsetting benefit) and further direct redistribution was already determined not to be optimal.

Note, moreover, that even if there were too little redistribution at the outset — the income tax was not set in a sufficiently redistributive manner — it still will be true that further indirect redistribution would not be optimal. As just explained, further direct redistribution, through the income tax itself, would be a dominant strategy. ${ }^{11}$

Cases in which savings should be taxed or subsidized; relevance for $\mathrm{t}_{\mathrm{g}}$. - Suppose that for some reason it is not optimal to set the tax rate on investment earnings (savings), $t_{r}$, equal to zero, but instead that it should be positive. (The reason may be due to violation of the separability assumption, the existence of externalities involving savings, or some other factor outside the present model.) The main point for present purposes is that this would not, in itself, provide any reason for imposing a positive tax, i.e., $t_{g}>0$, on $c_{g}$, playing golf in the second period. The reasoning is similar to that offered previously: a tax specifically on $c_{g}$ would distort the choice between it and $c_{2}$, without offering any benefit in return. If the motive for taxing $c_{g}$ was really that a higher tax on all consumption in period 2 would be optimal, it obviously would be best to raise that tax rate, $t_{r}$, directly.

This analysis also applies in reverse. Suppose one believed that the tax rate on secondperiod consumption (savings), $t_{r}$, was too high. It would not follow that it would be optimal to reduce an otherwise optimal tax on $c_{g}, t_{g}$ - whether from a zero level to a negative level (a

\footnotetext{
${ }^{11}$ This general idea (including the fact that it does not depend upon the preexisting income tax regime being optimal) has been developed in a long line of literature. See, e.g., Hylland and Zeckhauser (1979), Shavell (1981), Ng (1984), Kaplow (1996c). For some qualifications, see Slemrod and Yitzhaki (2000).

For political reasons, it is possible that a suboptimal strategy would be sensible when an optimal strategy is politically infeasible. Thus, perhaps, certain special interests successfully lobby for inefficient regulations that favor them when they believe that direct transfers, which would be more efficient, would be more visible and thus politically infeasible. With regard to the estate and gift tax, however, it seems unlikely that the rich are unaware that such taxes (as currently formulated) fall disproportionately on them, and thus that they would fail to oppose such a tax when they would have opposed income tax increases with a similar effect on themselves.
} 
subsidy) or from a positive level to a lower (or zero, or negative) level.

Reasons for setting $\mathrm{t}_{\mathrm{g}} \neq 0$. - Let us now consider what are the good reasons in the present setting to employ differential taxation among expenditures in period 2, that is, to choose $t_{g} \neq 0$. Initially, we should think of relaxing the assumption that $c_{g}$ and (period 1) leisure are weakly separable. Perhaps whether one's period 2 expenditures are on playing golf rather than on other goods and services affects the marginal utility of leisure after all. One view would be that golf is relatively time-intensive and thus is a leisure complement. But if we are considering playing golf during retirement (a useful interpretation of period 2 for present purposes), such a result is hardly obvious. In any event, when weak separability is violated, a differential tax - or subsidy, depending on the direction of the effect - may be optimal.

There are other, familiar reasons for imposing a differential tax (or subsidy) on a particular activity. The main one involves correcting for an externality. Some activities cause pollution or congestion, negative externalities, or provide direct pleasure to others or indirectly benefit them such as through network effects, positive externalities. Then a differential tax or subsidy, as the case may be, would be optimal.

\subsection{Analysis where $\mathrm{c}_{\mathrm{g}}$ refers to gifts}

We are now in a position to consider expenditures on gifts. We do not, however, begin in a vacuum. Rather, we begin from where we left off in subsection 2.3. That is, the benchmark in our minds at the outset should be the optimal treatment of an ordinary expenditure, and the baseline for that case is one of no differential tax or subsidy. If the optimal tax (or subsidy) on gifts should be different from this, it must be because of distinctive features of expenditures on gifts.

Following the analysis above, we can begin by inquiring whether expenditures on giving 
are leisure complements or substitutes, favoring a tax or subsidy, respectively, in order to mitigate the labor/leisure distortion caused by the income tax. To my knowledge, there has been no empirical study of this matter. As a matter of speculation, the answer is hardly obvious. On one hand, it might appear that gifts are a leisure substitute because, when one gives away income rather than spending it on oneself, say, for a vacation, one no longer needs as much leisure time to engage in consumption. On the other hand, an important use of leisure time may involve vicarious consumption through observing the direct consumption of donees - for example, spending time with one's grandchildren, whom one helps to support. (In the case of bequests, however, this factor would be inoperative.) Suffice it to say that too little is presently known to decide whether this consideration involving the interaction between giving and the demand for leisure is significant and, if so, which way it cuts. ${ }^{12}$

Next, we can inquire into the existence of externalities. In this respect, it seems that gifts typically are distinctive from ordinary consumption. Consider the case of true gifts, those that are not really part of an exchange (on which see subsection 3.3, below). Here, it seems that, ordinarily, the giving of a gift benefits not only the donor (who, one presumes, would not otherwise have made the gift) but also the donee. ${ }^{13}$ To formally introduce this into the preceding model, one could rewrite individuals' budget constraints as follows:

$$
w \ell+g-T(w \ell)=c_{1}+\frac{c_{2}+\left(1+t_{g}\right) c_{g}}{1+r\left(1-t_{r}\right)}
$$

\footnotetext{
${ }^{12}$ To illuminate this question, one could imagine studying, say, whether individuals who make larger gifts to their children are more likely to retire sooner or to work longer.

${ }^{13}$ This is another way of describing the familiar point that true gifts do not exhaustively consume resources but rather transfer command over the resources to another individual. The formulation presented in the text has the advantage of focusing attention on the presence of possible externalities, which, if present, have direct implications for policy design.
} 
where $g$ refers to the total value of gifts received. (The present notation implies that one receives gifts in the first period of one's life and also that the receipt of gifts is not independently subject to tax. Both simplifications are for convenience. ${ }^{14}$ ) This modification would seem to have two fairly direct effects. ${ }^{15}$

First, because donees are now better off, ceteris paribus, their utility is higher, and hence social welfare is higher. This involves a positive externality. See, e.g., Atkinson (1971, p. 222 n.1), Kaplow (1995), Stiglitz (1987, p. 1035). If this were the only consideration, it would appear that a gift subsidy, $t_{g}<0$, would be optimal.

Second, the receipt of gifts will have an income effect. Because donees are better off, as just described, their marginal utility of consumption will fall and, accordingly, we would expect their labor effort to fall. See, e.g., Holtz-Eakin, Joulfaian, and Rosen (1993), Imbens, Rubin, and Sacerdote (1999), Joulfaian and Wilhelm (1994). In the presence of an income tax, this involves a negative externality. See Kaplow (1998). The reason is that, when individuals are induced to work less, they do not take into account that they are contributing less to the government fisc. (This is simply another way of describing an aspect of the familiar labor/leisure distortion.) Interestingly, this factor raises the possibility that an individual's receipt of manna could reduce social welfare in a second-best world.

\footnotetext{
${ }^{14}$ The latter simplification is interesting because of the interaction between taxes on giving levied on donors and those levied on donees. Under most plausible formulations for individuals' utility functions, all that should matter is the aggregate net tax on the gift. To simplify notation, one can assume that any net tax or subsidy is levied on the donor. If one introduces further complications, such as nonlinear taxes, which may depend on the aggregate of gifts given or gifts received (the latter corresponding to an inheritance or accessions tax), then the present simplification would not suffice.

${ }^{15}$ There is a third effect that should be considered in a complete analysis: giving affects donors' and donees' marginal utility of income. See Kaplow (1998). One might suppose that this effect would be positive in the former case, because those who give spend less on their own consumption, and negative in the latter case. Differences in utility functions are usually ignored in welfare economic analysis because differences are assumed to be unobservable; implicitly, individuals are taken to have identical utility functions. But when giving patterns differ among otherwise similar individuals, the assumption of identical utility functions is no longer as plausible, and the observed differences in giving may be taken as indicators of differences in utility functions.
} 
A number of observations on these points are in order. Initially, something can be said about the optimal level of tax on transfers that is implied by consideration of the second factor alone. Receipt of a gift of magnitude $g$ should depress labor earnings, in the standard case, by an amount less than $g$. (The reason is that, when earnings fall by $g$, the marginal utility of income will be restored to its pre-gift level but, due to the fall in labor, the marginal disutility of labor will be somewhat lower, so the individual will wish to increase labor relative to that point.) It follows, therefore, that taxing $g$ at the donee's marginal income tax rate would be more than sufficient to make up for this externality. ${ }^{16}$ Interestingly, taxing $g$ at the donee's marginal income tax rate has been proposed by those who favor taxing gifts as income and forgoing a separate estate and gift tax system. (See, e.g., Simons (1938) and the discussion in subsection 4.6.) It should be recalled, however, that such a tax not only is more than what is required to account for the negative tax revenue externality, but also that such an analysis ignores the positive externality from giving.

In addition, it should be noted that, although the income effect usually involves a reduction in work effort and thus a negative tax revenue externality, this is not necessarily the case in the present context. For example, some gifts relax liquidity constraints and thereby facilitate investment by donees, whether in human capital or in entrepreneurship. See, e.g., Blanchflower and Oswald (1998), Cox (1990), Holtz-Eakin, Joulfaian, and Rosen (1994a, 1994b). Indeed, this prospect may motivate some gifts, or at a minimum affect their timing. In such cases, it would be possible to have a positive tax revenue effect because donees would

\footnotetext{
${ }^{16}$ The reason is that, as just explained, earnings would not fall by the full amount $g$, so a tax on the full amount would not be necessary to internalize the externality. (It should also be noted that imposing a positive tax on $g$ will lead to a reduction in $g$, which will reduce the income effect; nevertheless, the tax would be imposed on the resulting level of $g$ in any event.)
} 
ultimately earn more income on account of receiving gifts and thus pay more taxes. ${ }^{17}$

The remarks in the present subsection have been suggestive. Obviously, it would be useful to work out explicitly the optimal income taxation problem with transfer behavior fully incorporated. In doing so, one would need to make explicit the form of donors' utility functions that leads them to make transfers in the first place, which is the subject of the next section.

\section{Transfer Motives and Tax Policy}

Until the recent past, there was little interaction between the literatures on transfer motives and on tax policy. Recently, however, the importance of transfer motives to tax policy has been increasingly recognized. Nevertheless, it is worth pausing at the outset to reflect upon exactly why it is that motives matter. After all, motives did not play any direct role in the analysis in section 2 .

The first, and most obvious, reason that motives matter is that they bear on donors' behavior. In order to know whether and how much various tax regimes would influence gifts and bequests, it is necessary to understand why transfers are made in the first place.

A second reason — more direct even if less attended to — is that motives typically indicate the form of donors' utility functions which, in turn, indicate what utility donors receive from their giving. Moreover, motives may bear on donees' utility. These factors can have an important influence on optimal transfer tax policy. Consider two examples.

First, suppose that we are uncertain whether donors leave bequests "accidentally" (i.e., due to the incompleteness of annuity markets) or intentionally (say, due to altruism). Suppose,

\footnotetext{
${ }^{17}$ Donees' labor supply could be affected in other ways as well. There may, for example, be a further negative influence on account of the Samaritan's dilemma; that is, donees may work less hard, anticipating that altruistic donors (e.g., their parents) will bail them out. Or there may be the opposite effect: it may be understood that future gifts are contingent on productive behavior, leading donees to work harder or to invest more in their human capital in order to please prospective donors.
} 
now, that a confiscatory estate tax is under consideration. Even ignoring the effects of such a tax on behavior, the welfare assessment would be different depending on the motive. If bequests were purely accidental, the tax would reduce donees' (but not donors') utility with a corresponding gain to the fisc. If the bequests were altruistically motivated, then, in addition to these two effects, there would also be a reduction in donors' utility. Hence, it is conceivable that what would be a desirable policy given one motive would be a detrimental one given another. (To be sure, there would also be differences in behavioral effects, which would make the analysis more complicated.)

Second, consider an example in which it is unclear whether what appear to be gifts are "true gifts" or really involve some sort of exchange (perhaps the donee provides services to the donor). Suppose, moreover, that in either case a proposed tax would reduce giving to the same extent. Furthermore, we could suppose that the donor's utility loss from imposing the tax was the same, independent of the motive. It would remain true, nevertheless, that the welfare effects would differ. When the gift really involves an exchange, a lower gift implies a lower level of exchange; hence, the reduction in the donee's receipt is offset (at least in part) by the donee's providing fewer services. Thus, the donee's utility loss will be less than in the case of the pure gift, where the reduction in the donee's receipt will not be offset by anything.

The foregoing illustrations suggest that understanding donors' motives is extremely important in formulating estate and gift tax policy. The remainder of this section examines briefly a number of the motivations that have been offered in the literature and sketches some of their implications. ${ }^{18}$ To simplify the exposition, it will be useful to consider a one-period model,

\footnotetext{
${ }^{18}$ For discussions of transfer motives, see, e.g., Davies (1996), Masson and Pestieau (1997), Stark (1995). A more complete analysis of some of the issues discussed in this section appears in Kaplow (1998).
} 
where $c$ will denote the donor's expenditures on own-consumption. ${ }^{19}$ In addition, it will be imagined in each subsection that gifts are explained by a single motive, whereas in fact donors' motives may be mixed and different donors may have different motives. ${ }^{20}$

\subsection{Altruism}

Consider the following standard formulation of the altruistic donor's utility function:

$$
U\left(c, c_{g}, l\right)=\alpha u(c, \ell)+\beta v\left(c_{v}+c_{g}, \ell v\right)
$$

where $u$ is the donor's "self-regarding" utility function, $v$ is the donee's utility function, $c_{v}$ refers to donee's expenditures on consumption from disposable income, $\ell_{v}$ refers to donee's labor effort, and $\alpha$ and $\beta$ are weights (a relatively larger value of $\beta$ indicating a greater degree of altruism). For clarity, the gift, $c_{g}$, is entered explicitly in the donee's utility function rather than appearing through the donee's budget constraint.

The analysis in this case follows that already presented in subsection 2.4. Ignoring effects on tax revenue due to the donee's choice of labor effort, a gift subsidy (i.e., $t_{g}<0$ ) would be optimal because of the positive externality on the donee. Even though the donor is altruistic, the weight placed on the donee's utility is only $\beta$. By contrast, a utilitarian social welfare function would, with regard to a given donor/donee pair, place a weight of $1+\beta$ on the donee's utility, $v$,

\footnotetext{
${ }^{19}$ The donor's budget constraint for this version of the model is

$$
w \ell-T(w \ell)=c+\left(1+t_{g}\right) c_{g}
$$

${ }^{20}$ Such heterogeneity, combined with the government's presumed inability to observe motives directly, complicates the problem of policy formulation if indeed different motives imply that different policies are optimal. In practice, the government will have to base policies on averages, although sometimes it may be able to have policies depend upon observable features of gifts (such as whether the gift is financial or involves human capital, whether it is given during life or as a bequest, and how the donor and donee are related — see section 5) that are correlated with
} transfer motives. 
the 1 representing that the donee counts in his or her own right, and the additional $\beta$ reflecting the benefit to the donor from increases in the donee's utility. ${ }^{21}$ Hence, the donor's gift will be below the welfare-maximizing level in the absence of a subsidy. This is an instance of the positive externality from giving.

But it should also be apparent that a positive subsidy, which induces the donor to make a larger gift, will reduce the donee's labor effort and thus the level of income tax collections, producing a negative externality as well. In all, the case of altruistically motivated gifts fits well the analysis presented previously.

\subsection{Utility from giving per se}

Some donors may be motivated, not by altruism, but by the direct utility they receive from the act of giving, whether due to some internal feeling of virtue arising from sacrifice in the aid of others, a desire for prestige, or some other source of benefit. See, e.g., Andreoni (1990), who refers to this phenomenon as "warm glow" giving. For comparison with the case of altruism, the donor's utility function may be stated as

$$
U\left(c, c_{g}, l\right)=\alpha u(c, l)+\beta v\left(c_{g}\right)
$$

where $v$ is no longer interpreted as the donee's utility function but rather as a direct indicator of pleasure that the donor receives from the act of giving. The main difference, as is well known in the literature on transfer motives, is that $v$ does not depend on other sources of consumption for

\footnotetext{
${ }^{21}$ To illustrate, in a two-person society, the utilitarian social welfare function would be $\alpha u+(1+\beta) v$, the sum of the donor's utility function and the donee's. Some have questioned whether altruistic preferences should "count" in assessments of social welfare, but the reasons for ignoring tastes about others (such as those one loves) when counting all sorts of tastes (including preferences regarding the behavior of individuals one does not love, such as performers that one pays to see) are obscure. Moreover, using a social welfare function that omits altruistic utility would have troubling policy implications (for examples, bans on supporting children and on highly skilled individuals engaging in various low paying helping professions may be welfare-improving under such a view).
} 
the donee.

Despite the difference in motives, the analysis concerning the welfare effects of a tax or subsidy on giving is qualitatively similar. A subsidy will still increase the level of giving, the increase will involve a positive externality in that the greater gift benefits both the donor and the donee, and the gain to the donee will tend to affect tax revenue, negatively in the standard case.

It should be observed, however, that the preceding formulation (which is analogous to that used, e.g., in Andreoni (1990)), may not be the best representation of the stated motive. It is supposed that the donor is really motivated in a manner that depends on his or her own sacrifice, and not on the benefit to the donee from all sources (including the public fisc), as in the case of altruism. Accordingly, it would appear that the donor's benefit should not depend on the gross gift, $c_{g}$ - as in the above expression — but rather on the net amount that the donor actually gives up, which here is $\left(1+t_{g}\right) c_{g}$ - an amount that is less than $c_{g}$ when there is a subsidy (when $t_{g}<$ $0) .^{22}$ In this case, the donor's utility function would be

$$
U\left(c, c_{g}, l\right)=\alpha u(c, l)+\beta v\left(\left(1+t_{g}\right) c_{g}\right)
$$

The effect of a gift subsidy on social welfare is quite different under this formulation. A higher subsidy (a lower, or more negative, level of $t_{g}$ ) now has the direct effect of reducing the donor's utility from giving because a lesser sacrifice is involved for a given level of gift. A

\footnotetext{
${ }^{22}$ To test this intuition, suppose that the subsidy on giving were not given to donors at all, but instead were given directly to donees, in the form of a matching grant. Should one assume that donors who do not care directly about the donee's utility or about other sources of financial support the donee might receive view such a government grant as part of their own sacrifice? Another consideration is that, if donors cared only about their own sacrifice and not at all about what donees received, then a confiscatory tax on donees' gift receipts would not reduce donors' utility from giving, which seems implausible. Obviously, the factors determining donors' utility from giving — even assuming that the present motivation correctly describes an important fraction of giving — raises empirical questions that, as noted in the text to follow, do not seem to have been explored.
} 
higher subsidy (lower tax) may produce a larger gross gift, but the utility benefit to the donee is matched by a utility loss to the donor. The situation can be characterized as one involving induced redistribution rather than a double benefit. Hence, the optimal tax (subsidy) on giving would be higher (lower) if — taking as given that donors are motivated by the act of giving per se - it is the net sacrifice rather than the gross gift that determines the donor's level of utility. To my knowledge, the existing empirical work on this transfer motive does not attempt to determine which of these two versions more accurately describes such donors' behavior.

\subsection{Exchange-related motives}

The most straightforward instance of exchange-motivated giving occurs when the donor gives the donee resources in exchange for services. ${ }^{23}$ See Cox (1987). Here, the interpretation of the donor's utility function, $U\left(c, c_{g}, \ell\right)$ is simply that $c$ and $c_{g}$ are two different forms of ordinary consumption of goods and services. In this case, the analysis of subsection 2.3 is directly applicable: gifts are not distinctive and there is no a priori argument for applying any differential tax or subsidy. It also follows in this setting that "gift" receipts of donees should be included in their taxable income, for in the typical case the receipts are wages, although received in an informal market. ${ }^{24}$ It may be noted that this case supplied one of the motivations for Simons' (1938) argument that gifts should be taxed as income to donees.

Other forms of exchange are also possible. Notably, what may appear to be

\footnotetext{
${ }^{23}$ More subtle versions, such as the strategic motivation explored by Bernheim, Shleifer, and Summers (1985), are no different for present purposes. The argument in Buchanan (1983) that potential heirs will engage in rent-seeking behavior to induce donors to make transfers also seems similar if one supposes that such behavior involves providing something of value to donors.

${ }^{24}$ Interestingly, if the donee provided the same services as a gift — that is, with no payment expected in return - there would be no tax under the standard income tax system. The donee may be regarded as providing nonmarket labor services, but such imputed income generally is not taxed. Under current law, if the donor - without any formal obligation - reciprocates with a return gift, both halves of the transaction are exempt from the income tax, whereas if one transfer is the quid pro quo for the other, the exchange is subject to tax (although, as a practical matter, evasion on such transactions is undoubtedly high).
} 
unidirectional transfers may really be loans that are expected to be repaid or elements of various types of insurance and annuity schemes. ${ }^{25}$ See, e.g., Kotlikoff and Spivak (1981), Lucas and Stark (1985). These sorts of exchanges likewise do not call for any special tax or subsidy. Under an income tax, the proper treatment of many such arrangements is to ignore transfers, except when they involve (explicit or implicit) payments of interest; under a consumption tax (of a personal, cash-flow type), all receipts would be included in the tax base and all payments would be deductible.

\subsection{Accidental bequests}

Purely accidental bequests involve the transfer of remaining assets at death to one's heirs when the only reason any assets are in one's estate is on account of the inability to annuitize completely (and otherwise obtain insurance). To model this phenomenon obviously requires the introduction of uncertainty. The main ideas for present purposes, however, can be understood intuitively. First, there is the familiar point that, if bequests are purely accidental, they can be confiscated completely, with no effect on donors' behavior or utility. Yet this point does not, by itself, imply that such taxation would be optimal, for such a tax obviously reduces the utility of donees. $^{26}$

This leads to the second point, which concerns income distribution — or, from an ex ante perspective, allocation of risk. To make matters simple, assume that the revenue from estate

\footnotetext{
${ }^{25}$ Data on inter vivos transfers often do not distinguish among pure gifts, loans, loan repayments, insurance payments, and other forms of transfers, which makes the interpretation of empirical work difficult.

${ }^{26}$ It is also important to distinguish purely accidental bequests - from individuals who would prefer to annuitize completely - from bequests by individuals who cannot bring themselves to write a will or engage in other forms of planning. Even if the latter group were to exhibit little behavioral response to estate taxation, it still may not be optimal to impose such a tax because it is possible that such donors do derive utility from contemplation of their descendants' prospective inheritances, which would be reduced by the prospect that their bequest would be taxed.
} 
taxation would be distributed pro rate among members of the generation of prospective donees. ${ }^{27}$

Such an estate tax would operate as a pure insurance arrangement among donees: some would otherwise receive large bequests, others little or no bequest, but with the tax, all receive an equal amount. ${ }^{28}$ If individuals are risk averse, as most probably are, such a scheme would tend to raise welfare. $^{29}$

\section{Rethinking Standard Criteria for Assessing Estate and Gift Taxation}

As suggested in the introduction, the standard criteria for assessing estate and gift tax policy concern such matters as redistribution, raising revenue, effects on savings, and other considerations. Unfortunately, discussion of these desiderata often is not tied directly either to an explicit statement of ultimate objectives or to a formal analysis of the tax system as a whole. As a result, analysis is often incomplete or misleading. Some suggestion of the shortcomings appears in section 2. The present section offers a more complete examination of how optimal income tax analysis illuminates the standard criteria and sketches some further extensions of that analysis.

\subsection{Redistribution, conventionally understood}

Perhaps the most commonly suggested link between concerns about redistributing income from the rich to the poor and the instrument of estate and gift taxation is that transfers are made

\footnotetext{
${ }^{27} \mathrm{As}$ is familiar, if one were examining an optimal tax regime, then it would not matter at the margin how the revenues were used, in which case the scenario considered in the text would suffice to demonstrate the conclusion. In any event, the proposed thought experiment should serve to illustrate why steep taxation of bequests would tend to be optimal in the case of purely accidental bequests.

${ }^{28}$ One can usefully compare to confiscatory estate taxation the alternative scheme of taking individuals' assets — say, at age 65 - and giving back an annuity with a present value equal to the assets taken. If the reason for the failure to annuitize was adverse selection, such a solution might enhance welfare even more.

${ }^{29}$ It should be noted, however, that those receiving the largest bequests in the absence of taxation would be those whose parents died earliest. Such individuals might be supposed ordinarily to have lower utility than others on this account, and their larger bequests might be viewed as compensatory. The argument in the text implicitly assumes that such utility differences due to nonpecuniary factors do not affect individuals' marginal utility of income. In such a case, optimal insurance equalizes income, and thus marginal utility — not utility levels — across states of nature.
} 
disproportionately by the wealthy, so that an estate and gift tax system can aid in the redistributive enterprise. It was explained in subsection 2.3, however, that this intuition is in error, for it is generally better to increase the extent of redistribution — if that would be optimal — directly, through adjusting the income tax system.

One way to understand this basic point is to reformulate the question of optimal transfer tax policy as follows: As between two donors with identical income (etc.), should we tax (or subsidize) more heavily - and how much more - the one who spends an additional \$1 on a gift rather than on own-consumption? As explored in subsection 2.4 , there may well be reasons to tax more or less heavily expenditures that are made on gifts. But none of these considerations has any direct connection with increasing the extent of redistribution. That is, there is no particular reason (on purely redistributive grounds) that a rich person who spends a marginal dollar on a gift should be required to make a greater contribution to supporting the poor than an equally rich person who instead spend the marginal dollar on him- or herself.

The preceding discussion is, however, incomplete in an important respect. One should expand the analysis to take into account that multiple generations are involved and that gifts affect income distribution through effects on donees. Formally, the problem defined in section 2 could be extended in a number of ways. One would be to incorporate two generations that overlap (so that period 2 for the first generation was period 1 for the second, with gifts potentially being made during the period of overlap, from the older to the younger generation). Another way, which has been explored in some of the literature, involves incorporating an indefinite series of overlapping generations into the model. See, e.g., Bevan and Stiglitz (1979), Laitner (2000). To keep matters simple, most of the discussion to follow will speak in terms of the first version. Also, to make the exposition concrete and to focus on the most pertinent case, suppose 
that rich members of the first generation give disproportionately more than do others, that most of the giving is by individuals of above-average income taking the two generations as a whole, and that the average recipient is not as rich as the corresponding donor but is as rich or richer than average for members of the second generation. ${ }^{30}$

What, then, are we to make of a transfer from a member of the first generation to a member of the second? One perspective would be to examine the effect of transfers on the distribution of living standards within each of the two generations and for the two generations viewed as a whole. For the first generation, giving reduces inequality in living standards (because, by assumption, the rich give disproportionately more). For the second generation, giving increases inequality in living standards (because the average recipient is of at least the average living standard before receiving the gift). Finally, and perhaps most importantly, if the two generations are viewed as a single society for purposes of analysis, gifts reduce inequality; indeed, the typical gift can be seen as a sort of voluntary redistribution. ${ }^{31}$ To be sure, the reduction in inequality may not involve primarily transfers to the poorest members of society, most of whom do not have wealthy parents; nevertheless, the average gift involves moving resources to a donee whose standard of living is relatively lower than that of the corresponding donor.

A problem with the preceding analysis is that living standards are not the ultimate matter

\footnotetext{
${ }^{30}$ There are, of course, settings in which this description would be inaccurate. For example, if there were substantial regression toward the mean in income and if transfers were highly equalizing, it is possible that average recipients would be (pre-gift) of below-average income. See, e.g., Bevan and Stiglitz (1979).

${ }^{31}$ The discussion in the text sheds light on analyses that examine the effects of voluntary transfers — and of transfer taxation — on the steady state extent of inequality in an infinite, overlapping generations model. This measure of inequality is akin to focusing, in the present, simpler setting, on inequality in the second generation alone. As the point in the text suggests, and as Bevan and Stiglitz (1979) and others have previously noted, such a focus can be misleading.

Another issue raised by considering multiple generations is the problem of aggregation, sometimes addressed under the rubric of generational discounting. Exploring this issue, which obviously involves questions going well beyond estate and gift taxation, is outside the scope of the present inquiry. The basic points made in the text do not seem to depend on precisely how the matter is resolved.
} 
of concern; rather, it is supposed that social welfare consists in some aggregate of individuals' utilities, their levels of well-being. On this account, the analysis is more complicated, for gifts cannot be understood to reduce the utility (as opposed to the living standard) of donors, for otherwise they would not have made their gifts. Taking this into account, it seems entirely possible that gifts would increase inequality in utilities, combining the two generations together.

That said, there is a further, and more important difficulty with all of the analysis of intraand intergenerational inequality that has just been presented (and much of that in the literature): it considers inequality in a vacuum, rather than examining social welfare as a whole and taking into account the income tax system. Indeed, the preceding analysis suggests that, even if gifts are made disproportionately by the rich, it does not at all follow that gifts should be taxed to further redistributional objectives. Rather, it tends to be optimal to make adjustments in the income tax and transfer system. Whether gifts should be taxed (or subsidized) relative to expenditures by equally rich individuals on own-consumption depends not on the income level of donors, but rather on other factors identified in subsection 2.4, notably, the positive and negative externalities associated with gifts.

Moreover, even in a world with no income tax, confining attention to the effects of giving on inequality, rather than social welfare, can be problematic. Suppose, for example, that one is contemplating a simple policy of abolishing giving (which may well be the consequence of a confiscatory tax on giving, which some have proposed). Under the stated assumptions of the present example, such a policy would reduce inequality in utilities. (Abolishing giving would reduce the utility of donors who no longer have the utility-enhancing option of making gifts they, by assumption, are richer than average — and would reduce the utility of donees who no longer receive gifts - donees, by assumption, were of at least average income and of above- 
average income including their gifts.) Nevertheless, this inequality-reducing policy would be Pareto inferior, for it reduces the well-being of donors and donees and helps no one else. Even if one were to employ a social welfare function that was highly egalitarian, such a policy would reduce welfare as long as the welfare function respected the Pareto principle. Thus, knowing how a policy affects inequality — even combined with knowledge about how the policy affects total wealth - is insufficient in the present setting to determine even the direction of the effect of the policy on social welfare.

\subsection{Other distributive objectives}

The preceding subsection considered issues of inequality and redistribution using the framework that has become familiar in economic policy analysis. Not all distributive objectives that have been advanced, however, seem on their face to be reducible to such terms, and this is certainly the case with respect to public policy toward transfers, notably, involving the intergenerational transmission of wealth.

Perhaps the most common alternative criterion is some version of an "equal starting points" notion. Focusing on the generation of recipients of gifts, the concern is that inheritance (combined with inter vivos transfers) gives some individuals an unfair advantage over others. Sometimes the point is cast in terms of providing equality of opportunity (which could refer to the opportunity to enjoy life or to take advantage of various opportunities that are more accessible to those with greater initial wealth). Consider, now, two variations of this notion, which differ with respect to whether financial gifts are distinguished from other sources of unequal opportunity.

Under one view, the problem is with unequal opportunity, whatever its source. As will be discussed in subsection 5.1, the greatest cause of unequal starting points involves human capital 
— differences in genetic endowments, living environments, and other sources of parental support that affect future earnings and other life opportunities. ${ }^{32}$ Explicit transfers of the sort that are or may be subject to estate and gift taxation might in some instances mitigate such inequality but more often probably augment it (due to the positive correlation between parental financial resources and these other sources of inequality).

The problem of basic inequality, however, is familiar, and it is the problem that the standard welfare economic framework and optimal redistributive taxation analysis are designed to handle. From this perspective, there is nothing special about financial transfers. An extended optimal income tax framework, with overlapping generations and gifts, would already take the effect of transfers into account. And, whatever is the weight of the social concern for inequality, it will be reflected in the social welfare function. As already discussed, there is no simple, direct connection between the desire to redistribute income and the optimality of imposing high taxes on gifts.

Under another view, financial gifts are seen as a particularly undesirable source of inequality in starting points. Some have suggested a distinction between individuals' rights to the proceeds from their own labor and to the receipt of financial transfers from others. Although the grounds for this distinction are unclear, ${ }^{33}$ arguments of this sort have been offered in favor of taxation of gifts. Such an approach, however, is in fundamental conflict with the welfare

\footnotetext{
${ }^{32}$ See Davies (1982). For example, Bradford (1986) indicates that if a $90^{\text {th }}$ percentile male received, at age forty, the $90^{\text {th }}$ percentile inheritance, his lifetime wealth would increase by a mere $4.2 \%$.

${ }^{33}$ Some suggest that earned income should be treated preferentially to unearned income from inheritances. This view, however, ignores that earned income itself is largely determined by sorts of inheritance, as already noted in the text. Moreover, one should ask whether the view makes problematic the taxation of earned income under the income tax or under a consumption tax. (Indeed, if what appear to be gifts are really payments for services, it is generally uncontroversial that a tax should be levied on the transfer. As discussed in subsection 4.6, earned income is fully taxed whereas gift receipts are generally exempt under the U.S. income tax; this approach seems to be opposite to that suggested by this notion about how different sources of receipts should be treated.)
} 
economic approach of assessing policies based upon their effects on individuals' well-being and in a manner that suggests that the approach should not be followed.

It is useful to elaborate upon the latter point because the basic tension, although often acknowledged at some level, does not seem to be fully appreciated. Suppose, for example, that we would (that society should) be willing to sacrifice up to $R$ in resources to reduce inequality in the next generation by the amount $I$ when the inequality was due, say, to differences in talent, physical disabilities, or market luck. The posited distributive objective supposes that we should be willing to spend something more than $R$ in resources to reduce inequality in the next generation by the same amount I when the cause is financial inheritance. In principle, this would be the case even when those suffering from the inequality were the same people in both instances, since the notion depends on the source of reduced well-being and not purely on the extent to which well-being is reduced.

The foregoing analysis implies that, in a world in which ordinary constraints are present, following the prescription of this view will result in less reduction in overall inequality than if we gave no weight to this special notion. At whatever constrained optimum we could achieve under the proposed view, we could shift some resources from reducing inequality caused by financial inheritance to reducing inequality caused by other factors; by assumption, the marginal cost being incurred for inequality reduction is greater for the former than for the latter source of inequality. Hence, the shift could, at given cost, reduce inequality more. ${ }^{34}$ And because, as noted, this analysis holds true even when it is the same individuals who suffer from both sources of

\footnotetext{
${ }^{34}$ Suppose, for example, that at the posited optimum under the distributive view that gives special weight to inequality caused by financial inheritance, the marginal tradeoff between deadweight loss and given reductions in inequality is 12 for inequality due to financial inheritance but 10 for all other sources of inequality. One could then raise inequality with the former cause by 1.0 unit, freeing up 12 in resources, which could be used to reduce inequality due to other causes by 1.2 units.
} 
inequality, it follows that a change in policy that gives less weight to the posited principle could make everyone — in particular, the poorest members of society — better off.

Indeed, it is possible to show formally that any such principle that is not grounded exclusively in a concern for individuals' well-being (that is, a principle of assessment not based solely on utilities, but which instead looks, for example, to the sources of utility) will in some cases conflict with the Pareto principle. ${ }^{35}$ Thus, other distributive objectives - whether based on a notion of equal starting points or otherwise - are troubling, to the extent that individuals' well-being is deemed to be important in assessing social policy.

\subsection{Revenue}

It is sometimes suggested that estate and gift taxes are useful supplements to other taxes in raising revenue to finance public expenditures. In the present setting, this suggestion is misleading. As suggested briefly in subsection 2.2, the standard formulation of the optimal income taxation problem takes into consideration any social benefits from raising revenue, whether for financing redistributive transfers or for funding public goods. The analysis in the remainder of section 2 then explored when taxes (or subsidies) on giving — relative to other forms of expenditures by individuals - were optimal. Although the need to raise revenue is present in the background, it does not bear directly on the question of whether transfer taxation increases social welfare.

\footnotetext{
${ }^{35}$ See Kaplow and Shavell (1999). Seemingly non-welfarist distributive principles such as the equal starting points notion may, however, be understood differently, as focusing on a proxy indicator that is related to individuals' well-being rather than as constituting an independent evaluative principle, to be pursued at the expense of individuals' well-being. One interpretation would be that the notion refers simply to general concerns for inequality, urging us not to lose sight of the distributive impact of transfers on the donee generation. Another interpretation might be that the notion reflects concern about a particular sort of envy among members of the donee generation, suggesting that there is a negative externality produced by intergenerational transfers. Under that view, the relevant question would be the magnitude of such an externality (i.e., the strength of such individual tastes) and how it compares to other such externalities, which are noted briefly in subsection 4.8 .
} 
The most important exception to the conclusion that revenue-raising considerations should not guide estate and gift tax policy involves problems of tax enforcement. ${ }^{36}$ It is understood that tax avoidance can be a serious problem, even in developed economies with sophisticated enforcement machinery. As a consequence, it may be optimal to employ certain taxes that otherwise would be inefficient in order to address income tax noncompliance. The easiest example in which to see this point is to consider that excise taxes on luxury goods might be optimal because some individuals may earn high incomes in the underground economy that otherwise would go untaxed. If there are income groups for whom income tax evasion is substantial and difficult to eliminate but enforcement of estate and gift taxation is feasible, there would be grounds for favoring such taxation.

In practice, the appropriate role of transfer taxes in addressing enforcement gaps in the income tax (or in consumption taxes) is unclear. On one hand, if illegal sources of income are kept as cash or sent to untraceable offshore accounts, it seems unlikely that one could readily collect transfer taxes on such funds. On the other hand, it may be that some such income is laundered and then used to purchase assets in the regular economy. These assets may be observable as part of individuals' estates. In such cases, however, the optimally set consumption tax, applicable to the initial purchase of such assets, may suffice as a second-best instrument. Estate taxes might nevertheless be a useful supplement when assets are purchased secretly — or in other jurisdictions - but can be identified as part of an estate. In any event, this potential role of transfer taxation deserves further exploration, and it seems likely that a transfer tax system designed with such enforcement problems in mind would look rather different from that currently

\footnotetext{
${ }^{36}$ It is sometimes suggested that political constraints may favor use of transfer taxes rather than, say, greater progression of income taxes, although, as note 11 indicates, the basis for such a view is unclear.
} 
employed. (Notably, it might tax only certain sorts of assets, or provide for exemptions if assets were purchased through qualified accounts in which all deposits had been subject to income taxation. $)^{37}$

\subsection{Savings}

The relationship between transfer taxation and savings was explored (implicitly) in subsection 2.3. ${ }^{38}$ The main connection between transfer taxation and savings that has been identified is that donors often fund transfers out of their savings. This is not inevitably so; for example, transfers in support of minor children are often funded out of current earnings or even from borrowing. But many transfers, including bequests, come out of savings derived from previous receipts. ${ }^{39}$

As explained previously, one can, in the simple two-period model presented, view gifts as one type of expenditure in period 2, the other type being on own-consumption. A tax on giving is an example of a tax on a subset of consumption in period 2. (In subsection 2.3, recall, the problem was discussed with the differential tax being applied to expenditures on playing golf.) A tax on a subset of period 2 consumption can be viewed in part as a tax on period 2 consumption and hence as a tax on savings.

It is helpful, however, to decompose such a tax so that we can view separately its two components: an average tax rate on period 2 expenditures (whether gifts or own-consumption) and a differential tax/subsidy on particular components. Thus, a tax on gifts is equivalent to (1) raising the average tax rate on period 2 expenditures (taxing savings), by an amount equal to the

\footnotetext{
${ }^{37}$ See also subsection 4.5 , on whether estate and gift taxes do raise significant revenue and on their own compliance costs.

${ }^{38}$ Literature on transfer taxation and savings includes Johnson, Diamond, and Zodrow (1997), and Gale and Perozek (2000).

${ }^{39}$ It is familiar that this tendency poses an empirical puzzle, for giving earlier is tax-favored in the present U.S. estate and gift tax system, yet most gifts are delayed, often until the time of death. See, e.g., Poterba (1998).
} 
tax rate on gifts times the fraction of period 2 expenditures on gifts, combined with (2) a tax on gifts and a subsidy on own-consumption, which sum (in absolute values) to the originally posited tax on gifts.

Viewed in this manner, the analysis is straightforward. The first component is simply an ordinary tax on savings, which has been subject to extensive prior analysis. (The optimal income tax analysis of such a tax, in certain basic settings, was explored in subsection 2.3.) Obviously, one can in principle adopt such a tax without taxing transfers differentially. Likewise, if the effect of taxing transfers were thought to be detrimental because of how such a tax affects savings, one could offset such effects by directly adjusting the tax rate on savings. In addition, there are other policy instruments that may be used to influence savings more directly. See Stiglitz (1978). This suggests that estate and gift tax policy should probably be based on other considerations. (The reason for supposing that transfer taxes tend to be an inferior means to influence savings is that adjusting them from what would otherwise be optimal will involve a further distortion, involving transfer behavior, whereas interventions that act directly on savings will not have this effect.)

The second component, a tax on gifts relative to own-consumption, has nothing to do with savings per se. It is this aspect of the tax on gifts (or subsidy, as the case may be) that has been the subject of analysis in the rest of this essay. This is not to deny that a differential tax on different components of period 2 expenditure may have an effect on savings. It can - just as the case with any differential tax on different forms of expenditures. Such effects, however, will be more indirect than that attributable to the previously-described first component of a tax on transfers. It is important in analyzing the effects of transfer taxes on savings to distinguish these two components. Moreover, one should distinguish gross effects - which themselves may not 
have welfare consequences - from distortions, which ordinarily do adversely affect individuals' well-being.

\subsection{Administrative and compliance costs}

All actual tax systems, including systems of estate and gift taxation, involve administrative and compliance costs. Indeed, it is often suggested that these costs are particularly high for transfer taxes because large expenditures are made on expert advice and rearranging financial affairs and that these expenditures significantly reduce the tax owed, although it is not clear the extent to which this is actually the case. See, e.g., Cooper (1979), Munnell (1988), Schmalbeck (2000). It should be noted, however, that this point does not have obvious implications for tax reform, because such costs may be reduced either by eliminating transfer taxation or, perhaps, by making it more comprehensive (such as by eliminating tax benefits from inter vivos transfers, which are often made in complex ways in order for donors to retain control of resources during their lifetimes).

Another set of complications involves interactions between the income tax and transfer taxes. To some degree, one may serve as a backstop to the other. Such an argument is sometimes made relating to the U.S. income tax provision that steps up the basis of appreciated assets at death, estate taxes on the transfer of such assets substituting for capital gains taxation of the unrealized appreciation. ${ }^{40}$ When there exists a real problem, however, it is often better to deal with it directly, here, by changing the income tax treatment of capital gains, if that is indeed deficient. ${ }^{41}$ In addition, as discussed in subsection 4.3, it may be that one tax (the estate tax) is

\footnotetext{
${ }^{40}$ For empirical evidence on the relative magnitudes of savings in capital gains taxes from step-up and estate taxes paid, as a function of the size of estates, see Poterba and Weisbenner (2000).

${ }^{41}$ There are other possible shortcomings of the income tax that a transfer tax might play a role in remedying. For example, aggregate gifts and bequests may be correlated to lifetime income whereas the income tax is assessed on annual income. It would seem, however, that the correlation is significantly confounded by other factors (notably, saving and giving behavior, which vary even taking lifetime as given) and more direct solutions, such as restoring some degree of
} 
able to collect revenue on funds not previously taxed (under the income tax) due to evasion. Yet another interaction that has been explored is the possibility that attempts to avoid one tax affect receipts under the other, such as when estate tax planning reduces income tax receipts. ${ }^{42}$

The extent of administrative and compliance costs as well as the complex interactions between different tax systems are all relevant to a welfare economic assessment of estate and gift tax policy. Further analysis of the empirical and, in some cases, analytical issues that underlie these matters are beyond the scope of the present essay.

\subsection{Are gifts and bequests "income"?}

It has long been suggested that gifts and bequests are "income" to the donee and hence should be included in the donee's taxable income. ${ }^{43}$ This argument was made by Simons (1938) and has been subsequently advanced, sometimes to support income taxation of gift receipts as an alternative to estate and gift taxation.

If gifts and bequests were included as taxable income (they are excluded in the U.S. under $\S 102$ of the Internal Revenue Code), this would result in a major tax increase on transfers for the vast majority of the population, whose transfers are too low to be subject to estate taxation but who pay income taxes at nontrivial marginal tax rates. For the most wealthy, top income tax rates are currently below estate tax rates, so net transfer taxes would fall, although if income taxation were in addition to the estate and gift tax system, transfer taxes would rise substantially for this group.

The main point to be made regarding this argument about income taxation of gifts is that

explicit lifetime averaging, would be superior means of achieving such an end.

${ }^{42}$ For example, Bernheim (1987) indicates that this effect may result in an income tax revenue loss sufficient to offset the revenue raised through the U.S. estate and gift tax system. For a contrasting view, see Repetti (2000).

${ }^{43}$ Analogous reasoning can be offered with regard to a consumption tax: a gift would be viewed as consumption by the donor, and the donee's expenditure of the gift receipts would be viewed as another act of consumption. 
it is a semantic one that does not per se bear on social welfare. ${ }^{44}$ Whether a definition of "income" that includes transfer receipts is better in some sense as a matter of language usage does not inform us about the effects of taxation on individuals' behavior or on their well-being. Thus, a number of commentators have suggested abandoning such appeals to definitions when assessing tax policy, in favor of direct application of the welfare economic framework. That is the approach employed in this essay.

Note, furthermore, that it should not matter — either for determining individuals' behavior or for assessing effects on individuals' well-being — whether taxes on transfers are nominally levied as part of the income tax, through a separate estate and gift tax regime, or some combination of the two. Of course, certain differences may arise from using one or another approach — such as whether the marginal tax rate on gifts varies with one's annual earnings, one's total level of giving, or both — but such considerations are secondary and, if important, could be altered. Likewise, there may be differences in administrative and compliance costs between the regimes. (For example, if gifts were deemed to be income to donees, it may be more difficult for alleged tax evaders to claim that their unexplained cash holdings were gifts from a now-deceased relative and thus were properly not reported.)

\subsection{Concentration of wealth and power}

Estate and gift taxes are sometimes favored on the ground that they tend to diminish undesirable concentrations of wealth and power. To consider this objective, it is useful to distinguish two questions, whether and why society should seek to reduce concentrations of

\footnotetext{
${ }^{44}$ Another interesting point, advanced by Brennan (1978), is that the existing single tax levied on the donor, who earns the income, already serves to reduce the level of gifts. For example, if individuals give a fixed fraction of their disposable income, a tax that reduces disposable income by $t$ also reduces net gifts by $t$. One could argue that this point does not really suffice to establish that gifts are already "taxed" as "income," but this would merely extend the semantic debate without illuminating the welfare implications of transfer taxation.
} 
wealth or power, and, if such a goal is an important one, whether use of transfer taxation is a sensible means of pursuing it.

With regard to the first question, two opposing views are often expressed. On one hand, it is suggested that undue concentrations of wealth are undesirable. Among the more common reasons for this view is that wealthy individuals are able to obtain disproportionate influence, on the political system or otherwise, as a result. Perhaps they or those whom they favor would have an advantage in seeking elective office or inducing government officials to do their bidding.

On the other hand, it is argued that concentrations of wealth enhance democracy by providing important sources of countervailing power. It may be that incumbent individuals or political parties are sometimes able to insulate themselves from opposition forces, while the existence of outsiders with significant wealth makes it possible to unseat incumbents if they become too unresponsive. In this regard, it may be important whether a few families have large accumulations of wealth or there are many wealthy people, with differing interests and points of view. Clearly, further study is required to ascertain which, if either, of these views is compelling, and to assess other possible effects, positive or negative, of concentrations of wealth. ${ }^{45}$

Suppose, for sake of argument, that it is the case that those with large amounts of wealth exercise a disproportionate and undesirable influence on the political system. Is transfer taxation a sensible means of addressing this problem? The first point to observe is that the problem, as

\footnotetext{
${ }^{45}$ Separately, it is sometimes suggested that wealth should be taxed because holding wealth is itself a source of utility. There are two problems with this argument. First, as explained in subsection 4.1, a proper approach to social welfare maximization is not concerned with taxing utility per se. Second, that wealth may produce two sources of utility (one while it is held and another when it is consumed) has no implication regarding the marginal utility of holding wealth. Many activities produce utility in multiple ways (for example, health club membership may provide entertainment, offer an opportunity to meet people, contribute to health, and improve one's appearance). Regardless, maximizing individuals will equate the marginal utility of different activities (spending on food, health clubs, savings, and so forth) so that, regardless of the number of sources of marginal utility of an activity, the aggregate marginal utility from each activity will be equal (unless there are distortions, such as those caused by taxation).
} 
usually described, really involves wealth, not its transfer, suggesting that a wealth tax — or a steeper income tax that would regulate the accumulation process — is more suitable to the task. ${ }^{46}$ Relatedly, it is not clear that transferring wealth to the next generation is more problematic than using it to buy influence in the present generation. See McCaffery (1994) (noting, for example, wealthy individuals' expenditures in attempts to become elected to high public office). (Indeed, to the extent that transfers tend to spread the wealth more evenly, they may reduce concentration in the relevant sense.) Second, more focused regulation — such as limits on campaign contributions - seem more directly related to the problem. Nevertheless, if direct means are inadequate, there may be second-best grounds for resort to transfer taxation. ${ }^{47}$

\subsection{Symbolic effects of giving and of transfer taxation}

Another factor relevant to the social desirability of some policies concerns their symbolic effects. One reason symbolic effects may be relevant to social welfare is that individuals may have tastes for certain rules or regimes. (For example, they may find satisfaction in knowing that the legal system will punish individuals who commit heinous crimes, independent of the tendency of such punishment to reduce crime.) Another possibility is that certain laws or policies may reinforce or undermine various social norms that regulate society. (For example, laws requiring people to clean up after their dogs may send or reinforce messages about proper behavior that tend to be influential independent of formal enforcement, such as by inducing guilt

\footnotetext{
${ }^{46} \mathrm{~A}$ transfer tax might be thought of as a wealth tax that is imposed once a generation rather than, say, once a year or once and for all. (The existence in the U.S. of a spousal exemption and a generation-skipping transfer tax is consistent with this conception.) But generations vary greatly in length and, in any event, the amount of wealth transferred may not be that closely related to the amount held or used (whether to obtain influence or otherwise) during the donor's lifetime. It should also be clear that wealth taxes and transfer taxes have different effects on incentives, the former applying directly to the savings (wealth accumulation) margin and the latter applying to the choice between ownconsumption and giving, independent of whether one is expending current income, savings, or borrowing against future income.

${ }^{47}$ One might suppose that direct means are politically infeasible, in part perhaps due to the political power of the wealthy. If this is the case, however, one might suppose, as suggested in note 11 , that they would similarly oppose aggressive transfer taxation designed to address the same problem indirectly.
} 
feelings and the fear of social disapprobation.)

Some of the controversy surrounding transfer taxation may involve these factors.

Individuals may be envious of the rich (particularly those who live off inheritances) or may disapprove of their behavior (in general, or the particular act of spoiling their children), in which case heavy transfer taxation may seem appealing. On the other hand, transfer taxation may be viewed as a penalty on success - or, worse, on success combined with generosity toward one's children - in which case transfer taxation may be seen as undesirable because it is corrosive of social norms favoring hard work and caring for one's family. ${ }^{48}$

Regardless of the actual importance of these factors as a matter of social welfare, it does seem to be the case that a good deal of the political rhetoric about estate and gift taxation echos these themes. Relatedly, such factors may help to explain why estate and gift taxation is unpopular among individuals who are unlikely ever to have to pay the tax.

\section{Additional Topics}

A number of further considerations seem important in assessing estate and gift tax policy, some of which have received only limited attention in prior work. In this section, a brief sketch will be presented. More questions will be raised than answers offered, suggesting a number of avenues for further research.

\subsection{Human capital}

Begin with two factual observations. First, human capital is undoubtedly a substantial majority of all wealth. See, e.g., Davies and Whalley (1991), Jorgenson and Fraumeni (1989). It constitutes virtually all of wealth for a large segment of the population and, especially at younger

\footnotetext{
${ }^{48} \mathrm{With}$ regard to the former, opposition to applying estate taxes to successful small businesses may be viewed in this light (and, of course, also in the light of special interest pleading).
} 
ages, the bulk of wealth for all but a small fraction of society.

Second, contributions to human capital represent a sizeable fraction of all intergenerational transfers, broadly construed. ${ }^{49}$ Much of human capital is obviously attributable to our innate abilities, which may be described (not just metaphorically) as genetic inheritance. Many of the other leading contributors to human capital can also be traced to parents. Our environment — the atmosphere in our homes, the neighborhoods in which we grow up, the public schools we attend - are all determined significantly by parental choices, which are often made with effects on children in mind. The time parents spend with children (imputed income, which is untaxed under income and consumption taxes) also is an important factor. In addition, there are direct expenditures on education (private elementary and secondary schools, college, postgraduate education) and contacts, business opportunities, and other benefits that flow from parents to their children. Even the efforts individuals exert to develop and make use of their human capital are shaped both by genetic inheritance of various predispositions and by socialization that is determined in significant part by the aforementioned factors.

Interestingly, essentially none of this huge component of social wealth, much produced by various sorts of intergenerational transfers, is subject to estate and gift taxes, either existing or proposed. Most of these sources of human capital would be viewed as analogous to tax-free imputed income under an income tax or (in the case of genetic inheritance) simply ignored. Of course, the benefits of exemption from both income and transfer taxes (where applicable) is great. Even the most explicit of such transfers - tuition payments for post-secondary education — are exempt from transfer taxation in the U.S. (It should be noted, however, that all such transfers are implicitly taxed under income and consumption taxes, to the extent that the human

\footnotetext{
${ }^{49} \mathrm{On}$ the contribution of families to children's human capital, see Taubman (1996).
} 
capital is productive and ultimately gives rise to income and consumption thereof. ${ }^{50}$ )

If it is optimal to eliminate estate and gift taxation (and not to tax bequests and gifts under income and consumption taxes), this state of affairs is unproblematic. If, however, significant transfer taxes (or subsidies) are optimal, it should be considered whether there is good reason for heavily taxing (or subsidizing) some types of transfers while exempting others. ${ }^{51}$ Is the omission of human capital just an oversight, by the tax system, among scholars, and in popular beliefs? Or is there some fundamental difference that justifies exemption for one set of transfers but not the other?

As a benchmark, there would be seem to be a prima facie basis for assuming that transfers should be treated uniformly, for otherwise behavior would be distorted. Differential treatment would have to be justified by reference to the sorts of arguments developed in previous sections concerning the optimal tax treatment of transfers. To suggest one possible ground for a distinction, transfers of human capital may tend to create positive tax revenue externalities (because they result in greater earnings by the beneficiaries, to the benefit of the fisc on account of higher income and consumption tax revenues), whereas other transfers tend to produce a more typical income effect that depresses labor supply and thus generates a negative tax revenue externality. ${ }^{52}$ From other perspectives, such as that favoring equal starting points (see subsection 4.2), transfers of human capital may be the most problematic, whereas large receipts of financial

\footnotetext{
${ }^{50}$ If such income or consumption taxation is deemed sufficient, one must ask why analogous taxation of transfers of cash (or other financial or physical wealth) is deemed insufficient. That is, if earnings have already been taxed under an income tax, why is that not sufficient taxation if the subsequent income taxation of human capital transfers is deemed adequate? Likewise, under a consumption tax, if the ultimate taxation of consumption by donees of their earnings from transferred human capital is sufficient, why would the same level of taxation of other transfers not be enough?

${ }^{51}$ Analogous points regarding income versus consumption taxation of human versus physical and financial capital are developed in Kaplow (1994, 1996a).

${ }^{52}$ Other externalities might depend on whether gifts involve human capital. For example, envy of those who live lives of leisure may be greater than envy of individuals whose education or businesses are subsidized but who must work hard in order to reap the benefit. Gifts of human capital may also reduce socially undesirable behavior (notably, crime) more than in the case of financial transfers.
} 
wealth later in life may be less offensive.

Other differences between the two types of transfers should be studied as well. Perhaps motives that typically underlie the creation or transferring of resources that contribute to human capital differ from those behind other transfers. This would suggest that taxation of the two different categories of transfers would have different behavioral and welfare effects. Whether the difference would favor more generous treatment of human capital transfers, as now exists, is an open question. In sum, human capital is simply too large a fraction of wealth and of intergenerational transfers to be ignored in serious study and analysis of estate and gift tax policy.

\subsection{Inter vivos gifts versus bequests}

The present essay, like much work on estate and gift tax policy, has for the most part not carefully distinguished inter vivos gifts from bequests. To the extent that the issue is addressed in the literature, the most common view seems to be that the two types of giving, which are often close substitutes for both donors and donees, should be treated in a unified manner. The 1976 tax reform in the U.S. was designed to move in this direction, although significant gaps remain and are the subjects of many reform proposals. ${ }^{53}$

Although the assumption that inter vivos gifts and bequests should be viewed symmetrically in tax policy analysis seems to be the right starting point, a number of differences can be noted. Inter vivos gifts, especially those given when donees are younger, may have different effects on donees. Early gifts may contribute to human capital, as discussed in subsection 5.1; they may relax liquidity constraints, allowing donees to engage more freely in

\footnotetext{
${ }^{53}$ Not all of the gaps and loopholes, however, favor inter vivos giving; transferring appreciated assets at death can have the advantage of saving capital gains taxes, due to the step-up of basis. Also, it should be noted that one of the more significant gaps, involving charitable transfers (see subsection 5.4, below), is not usually mentioned. There, even ignoring the estate and gift tax system, there is a large income tax benefit from inter vivos giving, namely, one gets a full income tax deduction for such gifts (up to certain limits that most individuals do not reach) but no such deduction from pure bequests.
} 
entrepreneurial activity; and so forth. Later gifts and bequests are less likely to have such effects. Those received mid-career may primarily have an income effect, depressing work effort. Those received during retirement may have no labor supply effect. On the other hand, anticipation of such gifts and bequests may affect labor supply negatively and also should be expected to reduce savings..$^{54}$

One should also consider donors. Perhaps earlier gifts (as noted in subsection 5.1) may, on average be given based on different motives than later gifts or bequests. ${ }^{55}$ If so, this will bear on donors' behavior and their welfare. Because motives cannot be observed directly by the government, it might make sense to treat differently various types of behavior (such as inter vivos giving versus bequests) that may signal different underlying motives. It also seems relevant in this regard, as explored in subsection 5.5, that donors' inter vivos gifts are substantially lower than optimizing behavior — taking into account the tax benefits of inter vivos giving - would seem to imply, which raises questions about whether their motivations are well explained by existing theories of transfer behavior. See, e.g., Poterba (1998).

Of course, whatever conclusions one reaches in principle about the appropriate difference between optimal taxation of inter vivos gifts versus taxation of bequests, maintaining asymmetric rules will create planning opportunities. These will both tend to reduce the effect of any

\footnotetext{
${ }^{54}$ In considering effects on savings, even if they are relevant to policy (see supra subsection 4.4), one should be careful to keep track of donors and donees together. See Gale and Perozek (2000). The donee who is saving less may be matched by a donor who is saving more, later to make a gift from such savings. By contrast, suppose that the donee receives the gift earlier in life. Then the donor is not saving as much. On the other hand, the donee - assuming that the gift will be spent in the same periods as it would have been spent if it was received late in life - will be saving correspondingly more. Thus, it is not clear that the timing of gifts will directly affect net savings. When the timing and extent of transfers are uncertain, however, one would expect there to be an effect; most likely, early giving would reduce saving by donees more than would later giving with the same expected value. Also, if recipients are liquidity constrained, earlier gifts would tend to reduce net savings.

${ }^{55}$ For example, purely accidental transfers (accidental bequests) would not emerge as inter vivos gifts. Also, some evidence suggests that the pattern of inter vivos giving (which favors poorer children) is more consistent with altruism than that of bequests (which tend to be divided equally). See, e.g., Dunn and Phillips (1997).
} 
difference in stated tax rates and also lead to additional expenditures of resources on tax planning.

\subsection{Distinguishing among different donor-donee pairings; taxation of the family}

Under estate and gift tax regimes, different donor-donee pairings are often taxed quite differently. In the present system in the U.S., for example, transfers between spouses are completely exempt, certain forms of transfers to children (notably, support and education, as well as many in-kind transfers) are exempt, other transfers to children and most transfers to others (that is, other humans, not charitable organizations) are taxed, and transfers to more distant generations are subject to an additional, generation-skipping transfer tax as well.

A natural presumption would seem to be that, whatever is the optimal differential taxation of transfers (versus expenditures on own-consumption), all donor-donee pairings should be treated in the same manner. Yet, there are reasons that may justify differences ${ }^{56}$ Notably, as discussed in section 3, it may be that different levels of taxation (or subsidy) are optimal, depending on donors' motives. But, as noted in the preceding subsection, if different motives cannot be observed directly and, moreover, certain observable characteristics (such as the relationship between the donor and donee or the type of gift) are signals of different motivations, then different tax treatment may be appropriate. Further work must be undertaken, however, to determine the relationships, if any, between possible categories of donees and various transfer motives in order to determine which distinctions, if any, are welfare promoting. ${ }^{57}$

Finally, it is worth connecting the present discussion to the problem of the optimal tax

\footnotetext{
${ }^{56}$ For reasons relating to the distribution of wealth, see Cremer and Pestieau (1988).

${ }^{57}$ Another question concerns whether any tax or subsidy should be applied to donors, as is done under an estate and gift tax system, or to donees, as is done under inheritance or accessions taxes. This question becomes relevant when the tax or subsidy is not applied at a uniform rate, but may depend on the totality of gifts given or gifts received (particularly when a single donor gives to multiple donees or a single donee receives gifts from multiple donors) or may depend on donors' or donees' marginal income tax rates in a graduated income tax system.
} 
treatment of different family configurations. The proper income tax (or consumption tax, or welfare program) treatment of different types of family units has proved contentious, and existing practices vary significantly among countries. The important point for present purposes is that a major defining feature of a family, from the perspective of use of resources, is that there is substantial (even if incomplete) sharing of income. That is, there are significant transfers among household members, usually from earners to others (whether to spouses who earn less or do not provide market labor or to children). Related to the foregoing discussion, there arises the question of how, if at all, such transfers should be taxed, in principle. ${ }^{58}$ The further suggestion here is that this question is intimately related to family unit issues under other tax systems, for what matters to particular families, with particular patterns of earnings, sharing, and expenditures, is the aggregate tax burden they bear, not how much of their tax obligation is denominated as arising under the income tax or under transfer taxes. Indeed, the method of taxing different family units can be interpreted as corresponding to different forms of presumptive taxation of transfers within the family ${ }^{59}$

\subsection{Charitable gifts and bequests}

A significant (although minority) fraction of giving, inter vivos and at death, is to donees that are charitable institutions. Moreover, the U.S. estate and gift tax system, through an exemption for charitable gifts, provides a large implicit subsidy to such transfers in the case of wealthy individuals who would pay significant estate and gift taxes if they instead transferred such funds to individual donees. See, e.g., Auten, Clotfelter, and Schmalbeck (2000), Joulfaian

\footnotetext{
${ }^{58}$ Administrative considerations, such as the difficulties of untangling the sources and uses of funds within a household, may favor certain regimes, such as exemption of intra-household transfers.

${ }^{59}$ For exploration of some aspects of the problem of income taxation of families, which takes account of the nature of intra-family transfers, see Kaplow (1996b).
} 
(2000). (By contrast, there is no estate and gift tax preference for charitable transfers versus own-consumption, although there is an income tax preference for such transfers. ${ }^{60}$ )

To analyze tax policy toward such transfers, it is useful to apply the analysis developed in sections 2 and 3, supplemented by consideration of the distinctive features of charities as recipients. Thus, in the model described in section 2, one could decompose second-period expenditures on gifts, $c_{g}$, into two components, $c_{g c}$ and $c_{g i}$, corresponding to gifts to charities and to individuals, respectively; similarly, one could tax (or subsidize) each type of gift at its own rate, $t_{g c}$ or $t_{g i}$. The analysis could then proceed in three steps.

First, as before, one would consider gifts as if they were simply another form of ordinary consumption and determine what, if any, differential taxation (versus expenditures on ownconsumption in the second period) was optimal. Second, one would again examine the distinctive features of gifts, now as a whole (considering both gifts to charities and to individuals). Observe, importantly, that most of the considerations examined in this essay in the context of what were presumed to be gifts to individuals are applicable to gifts to charities as well. Thus, it is the case that gifts to charities similarly involve a transfer of resources, which provides utility both to donors and donees. Likewise, the range of motives for giving explored in section 3 all seem potentially applicable to gifts to charities (with the possible exception of purely accidental bequests). Hence, arguments about the optimal taxation of transfers that depend on different types of transfer motives seem presumptively applicable to charitable gifts (although the frequency of different types of motives may well differ between the two types of gifts).

\footnotetext{
${ }^{60}$ As indicated in note $\underline{53}$, in examining the incentives under the current U.S. estate and gift tax regime to make inter vivos gifts rather than bequests, the charitable donation deduction under the income tax — a significant preference favoring gifts rather than bequests - must be kept in mind.
} 
These points are emphasized because it seems that, in tax policy analysis and debate, charitable giving is often treated as if it were an entirely separate subject from ordinary giving. ${ }^{61}$ Yet, in many respects, charities can be viewed as representatives or conduits that serve as intermediaries between donors and ultimate recipients. For example, giving to an organization that provides shelter for homeless people is analogous to making many small gifts to homeless people; the organization may realize economies of scale, represent donors' paternalistic wishes, and so forth, but the ultimate beneficiaries are still the individuals whom the organization serves. $^{62}$

There should, however, be a third step in the analysis, which asks what (if anything) is distinctive about gifts to charities, compared to gifts to individuals. (This is, of course, analogous to the second question, emphasized in section 2, concerning what is distinctive about gifts in general, compared to expenditures on own-consumption.) The preceding point suggests that little may in fact be distinctive, but there still might exist important differences, at least on average, that may warrant differential treatment. In particular, gifts to charities often involve public goods. For example, it may be that only parents or close relatives care especially about a particular child, who even without the gift would get along well in life, whereas a large number of people may have a sympathetic interest in the plight of the poor. ${ }^{63}$ See Hochman and Rodgers

\footnotetext{
${ }^{61}$ This point is applicable not only to estate and gift taxation per se, but also to income (or consumption) tax treatment of various types of gifts.

${ }^{62}$ The argument is more indirect, although conceptually similar, for other types of charities. Thus, gifts to support medical research can be seen as gifts to individuals why may ultimately benefit from such research.

${ }^{63}$ Preferential tax treatment of charitable giving is often advocated on grounds that it is redistributive. In addition to the public goods argument made in the text, further redistribution generally is beneficial from the perspective of overall social welfare, assuming that one's social welfare function is sufficiently egalitarian. The problem of the optimal mix of redistributive taxation and subsidy to voluntary redistribution merits further study. There is the separate question of the extent to which gifts are indeed redistributive. As noted in subsection 4.1, there is a sense in which most gifts to individuals are redistributive, and the same is probably true of gifts to charities. For example, among those who regularly attend the opera, it is probably true, on average, that the largest donations come from the richer patrons, to the benefit of all opera-goers. On the other hand, redistribution from rich opera supporters to average opera afficionados is not the sort of redistribution that most advocates of the present argument probably have in mind. And, one supposes, a
} 
(1969). Likewise, funding for the arts, medical research, or religious institutions may benefit many others, beyond the donor's immediate family. Hence, there may well be reasons for preferring charitable giving over other giving or other forms of expenditure.

Nevertheless, it is not obvious that the existing scheme of tax preferences is optimally designed to serve this purpose. In particular, the level of subsidy under the estate and gift tax depends primarily on the level of one's giving to individuals (for that determines one's marginal tax rate). It does not depend on the nature of the organization and hence on the extent to which one's gift funds valued public goods that benefit a large number of individuals. Moreover, it should be clear that if it is optimal to subsidize charitable giving, it is hardly necessary to do it through the transfer tax system. If, for example, it turned out that transfer taxation of ordinary gifts was not optimal but subsidization of charitable gifts was, one could simply operate a direct subsidy on charitable giving, such as through matching grants.

\subsection{The possibility that transfers are not the result of maximizing behavior by donors}

Not all economic behavior is accurately described as the product of the pure maximizing behavior that is stipulated in many economic models. In many settings, departures from rationality may be insignificant or may have little effect in the aggregate. It is hardly obvious, however, that the same can be said in the present context. First, it is well known that a substantial portion of donors who will be subject to transfer taxation fail — by a wide margin to take full advantage of inter vivos giving opportunities that would reduce their tax burden. See, e.g., Poterba (1998). Moreover, although some of this behavior can be explained on rational grounds, the evidence seems to suggest that a good deal of it cannot (or at least not in a

significant fraction of charitable giving — to the arts, to educational institutions, to one's own religious institutions (such as a local church or synagogue) — involves the support of organizations that benefit individuals who have levels of income not that different from those of many donors. 
straightforward manner that would be consistent with the standard models of transfer behavior). Second, it is often suggested that many donors are uneasy about contemplating their own death and that this unease may affect their transfer behavior. It should be noted that this sort of consideration may help to explain the difficulty of reconciling the empirical evidence on transfer behavior with any of the transfer motives that have seemed most plausible to researchers. Hence, it seems that this aspect of donors' behavior deserves further study.

Pending the outcome of such work, it is worth contemplating briefly the possible implications of nonmaximizing behavior - in particular, of the sort often postulated in the present setting - for transfer tax policy. Some have suggested that the presence of such behavior strengthens the case for high estate taxation, for if individuals do not think about what happens after death, there will be no incentive effects (on labor supply, savings, and giving) of such a tax. Of course, the extent to which this is true is ultimately an empirical question, and the simple version of the argument is unlikely to be substantially true, as evidenced by the large expenditures on estate tax planning and avoidance. Moreover, it does not follow from individuals' resistance to planning — or to making early transfers — that their behavior will be unaffected. If their bequests are not truly accidental (in the sense discussed in subsection 3.4), it is still possible that they adjust their labor supply, savings, and giving in the light of the anticipated tax burden. And, in any event, if they do receive utility from the contemplation of their children's enjoyment of funds that are transferred and they are aware of the tax, it will have the effect of reducing the well-being of donors and donees even if donors' giving behavior does not react much to the tax.

Separate from the unease of contemplating death is the phenomenon that individuals may behave myopically, greatly discounting the future. This topic has received attention recently in 
many contexts, including the analysis of savings behavior. See, e.g., Laibson, Repetto, and Tobacman (1998). From this perspective, it might seem that taxes in the future, including estate taxes (and gift taxes, which may be incurred long after income is earned and has been saved) would have less of an effect on behavior. ${ }^{64}$ (A more dramatic implication might be that repeal of the income tax and payroll tax, substituting consumption taxes, would greatly reduce labor supply distortions because much consumption — notably, retirement spending — is delayed until long after the time that the money is earned.) It should also be noted that a given behavioral response to taxation will be more distortionary if, for example, due to individuals' failure to behave rationally, their decisions concerning earning, saving, and giving are already distorted in the same direction.

Whatever the precise nature of any departures from maximizing activity in the present context, it should be clear that they may upset a wide range of the arguments presented throughout this essay. And, in particular, presumptions such as one that inter vivos giving and bequests should be taxed neutrally may be weakened significantly. For example, taking the simple and extreme case in which some individuals are rational maximizers and some do not think about their bequests or estate taxes at all, it may be optimal to employ high (even confiscatory) estate taxes, allowing for easy avoidance through inter vivos gifts. ${ }^{65}$ The only taxes collected would be on individuals whose behavior and utility is unaffected, whereas for the group on whom it might be inefficient to impose the tax, the tax would be fully avoided, and at little

\footnotetext{
${ }^{64}$ Whether this is true will depend on the particular model. (As one illustration of a different possibility, suppose that individuals in their high-earnings and savings years are well aware that there is a steep estate tax, but do not engage in tax planning until their later years, at which time they learn they can avoid much of the tax; then, their behavior in earlier years may implicitly be affected as if the effective estate tax rate were higher than it actually is.)

${ }^{65} \mathrm{Or}$, to consider another example, if donors' irrationality consisted in thinking only about the taxes that they themselves paid and not about the net gift received by donees, then switching from an estate and gift tax system to an inheritance or accessions tax regime, wherein the tax is instead imposed on the donee, would avoid distortions of donors' behavior.
} 
cost. One of the main purposes of considering such an example and exploring the topic more generally is to highlight the potential benefit of further investigation of this dimension of transfer behavior.

\subsection{Political economy of estate and gift taxation}

The present inquiry is concerned with offering a normative and analytical framework to assess estate and gift tax policy, in particular, to determine what sort of policy best advances social welfare, understood as some aggregate of the well-being of individuals in a society. A rather different question concerns what sort of estate and gift tax regime would be adopted under the assumption that the legislative process is largely controlled by self-interested political actors. The political economy of estate and gift taxation, however, is a subject outside the scope of this essay.

Nevertheless, some of the analysis presented here may bear on transfer tax politics. First, the analysis clarifies what the effects of transfer taxation are likely to be under various assumptions. Second, it has been suggested that transfer taxes, in the context of a larger tax system, may have a different role to play regarding redistribution, raising revenue, influencing savings, and other matters from what is commonly understood. It is possible that improved understanding of these interactions would influence which groups favor which reforms. Finally, the foregoing may shed some light on popular views regarding estate and gift taxation, which are sometimes viewed as a bit of a mystery since many who are probably beneficiaries of such taxation seem to favor its reduction or repeal. (See, for example, the discussion in subsection 4.8, concerning symbolic effects of transfer tax policy.) 


\section{Conclusion}

The two main themes of this essay have been to relate the many criteria that have been used to assess gift and estate taxes explicitly to the standard welfare economic framework and to integrate analysis of transfer taxation with that of the income tax. When transfers are viewed simply as one of many forms of expenditures that donors may make, a number of insights into the optimal taxation of giving can be obtained. This analysis, however, had to be modified in important ways to take into account the distinctive nature of gifts and bequests, namely, that expenditures on transfers tend to raise donors' utility by transferring resources rather than by using them up, as in the case of ordinary consumption. On one hand, this suggests that gifts often involve positive externalities, because donees benefit along with donors when the latter choose to spend on gifts rather than on own-consumption. On the other hand, the receipt of gifts may well have an effect on donees' labor supply, reducing it in the standard case, resulting in a negative tax revenue externality. It was seen, however, that this analysis is applicable directly only to pure gifts of certain types; other transfer motives are associated with different welfare consequences.

A number of the traditional criteria for assessing transfer taxation, as well as standard arguments that appeal to them, were seen to be incomplete or even misleading once the explicit welfare economic analysis, taking into account the income tax, was performed. Other familiar concerns are indeed valid, but can be better illuminated if one adapts the framework that has been developed by economists to analyze other aspects of the tax system.

The present investigation is incomplete: it offers a preliminary sketch of issues rather than a thorough, rigorous analysis, it does not provide the empirical evidence necessary to resolve important questions, and it only suggests how one might incorporate additional dimensions, such 
as the treatment of human capital, different giving patterns and family configurations, and transfers to charitable organizations. Much research remains to be done, and it is hoped that this essay will be helpful in organizing part of the necessary agenda. 


\section{REFERENCES}

Aaron, Henry J., and Munnell, Alicia H. "Reassessing the Role for Wealth Transfer Taxes." National Tax Journal, June 1992, 45(2), pp. 119-43.

Andreoni, James. "Impure Altruism and Donations to Public Goods: A Theory of Warm-Glow Giving?" Economic Journal, June 1990, 100(401), pp. 464-77.

Atkinson, A.B. "Capital Taxes, the Redistribution of Wealth and Individual Savings." Review of Economic Studies, April 1971, 38(2), pp. 209-27.

and Stiglitz, Joseph E. "The Design of Tax Structure: Direct versus Indirect Taxation." Journal of Public Economics, July-August 1976, 6(1-2), pp. 55-75.

Auten, Gerald E., Clotfelter, Charles T., and Schmalbeck, Richard L. "Taxes and Philanthropy Among the Wealthy," in J. Slemrod, ed., Does Atlas Shrug? The Economic Consequences of Taxing the Rich. Cambridge: Harvard University Press, 2000.

Bernheim, B. Douglas. “Does the Estate Tax Raise Revenue?”, in L.H. Summers, Tax Policy and the Economy, Vol. 1. Cambridge: MIT Press, 1987, pp. 113-38.

, Shleifer, Andrei, and Summers, Lawrence H. "The Strategic Bequest Motive." Journal of Political Economy, December 1985, 93(6), pp. 1045-76.

Bevan, D.L. and Stiglitz, J.E. "Intergenerational Transfers and Inequality." Greek Economic Review, August 1979, 1(1), pp. 8-26.

Blanchflower, David G., and Oswald, Andrew J. “What Makes an Entrepreneur?" Journal of Labor Economics, 1998, 16(1), pp. 26-60.

Bradford, David. Untangling the Income Tax. Cambridge: Harvard University Press, 1986.

Brennan, Geoffrey. "Death and Taxes: An Attack on the Orthodoxy." Public Finance, 1978, 33(3), pp. 201-24.

Buchanan, James M. "Rent Seeking, Noncompensated Transfers, and Laws of Succession." Journal of Law and Economics, April 1983, 26(1), pp. 71-85.

Cooper, George. A Voluntary Tax? New Perspectives on Sophisticated Tax Avoidance. Washington, D.C.: The Brookings Institution, 1979.

Cox, Donald. "Motives for Private Income Transfers." Journal of Political Economy, June 1987, 95(3), pp. 508-46.

. "Intergenerational Transfers and Liquidity Constraints." Quarterly Journal of 
Economics, February 1990, 105(1), pp. 187-217.

Cremer, Helmuth, and Pestieau, Pierre. "A Case for Differential Inheritance Taxation." Annales D'Économie et de Statistique, January/March 1988, 9(special issue), pp. 167-82.

Davies, James B. "The Relative Impact of Inheritance and Other Factors on Economic Inequality." Quarterly Journal of Economics, August 1982, 97(3), pp. 471-98.

. "Explaining Intergenerational Transfers," in P.L. Menchik, ed., Household and Family Economics. Boston: Kluwer Academic Publishers, 1996, pp. 47-82.

and Whalley, John. "Taxes and Capital Formation: How Important Is Human Capital?," in B.D. Bernheim and J.B. Shoven, eds., National Saving And Economic Performance. Chicago: University of Chicago Press, 1991, pp. 163-200.

Dunn, Thomas A., and Phillips, John W. "The Timing and Division of Parental Transfers to Children.” Economics Letters, February 1997, 54(2), pp. 135-37.

Erreygers, Guido, and Vandevelde, Toon. Is Inheritance Legitimate? Ethical and Economic Aspects of Wealth Transfers. Berlin: Springer-Verlag, 1997.

Gale, William G., and Perozek, Maria G. "Do Estate Taxes Reduce Savings?," in W.G. Gale, J.R. Hines, and J. Slemrod, eds., Rethinking Estate and Gift Taxation. Washington, D.C.: Brookings Institution, 2000.

Graetz, Michael J. "To Praise the Estate Tax, Not to Bury It." Yale Law Journal, December 1983, 93(2), pp. 259-86.

Hochman, Harold M., and Rodgers, James D. "Pareto Optimal Redistribution." American Economic Review, September 1969, 59(4), pp. 542-57.

Holtz-Eakin, Douglas, Joulfaian, David, and Rosen, Harvey S. "The Carnegie Conjecture: Some Empirical Evidence.” Quarterly Journal of Economics, May 1993, 108(2), pp. 413-35.

- "Sticking It Out: Entrepreneurial Survival and Liquidity Constraints.”' Journal of Political Economy, February 1994a, 102(1), pp. 53-75.

Rand Journal of Economics, Summer 1994b, 25(2), pp. 334-47.

Hylland, Aanund, and Zeckhauser, Richard. "Distributional Objectives Should Affect Taxes but Not Program Choice or Design." Scandinavian Journal of Economics, 1979, 81(2), pp. 264-84.

Imbens, Guido W., Rubin, Donald B., and Bruce Sacerdote. "Estimating the Effect of 
Unearned Income on Labor Supply, Earnings, Savings, and Consumption: Evidence from a Survey of Lottery Players.” NBER Working Paper No. 7001, March 1999.

Johnson, Craig E., Diamond, John, and Zodrow, George R. "Bequests, Saving, and Taxation," in 1996 Proceedings of the National Tax Association. Washington, D.C.: National Tax Association-Tax Institute of America, 1997, pp. 37-45.

Johnson, Barry W. and Mikow, Jacob M. "Elements of Federal Estate Taxation," in this volume, 2000.

Joint Economic Committee, Congress of the United States. The Economics of the Estate Tax. Washington, D.C.: Government Printing Office, December 1998 (printed 1999).

Jorgenson, Dale W. and Fraumeni, Barbara M. "The Accumulation of Human and Nonhuman Capital, 1948-84," in Robert E. Lipsey and Helen Stone Tice, eds., The Measurement of Saving, Investment, and Wealth. Chicago: University of Chicago Press, 1989, pp. 227-82.

Joulfaian, David. "Charitable Giving in Life and at Death,” in this volume, 2000.

and Wilhelm, Mark O. "Inheritance and Labor Supply." Journal of Human Resources, Fall 1994, 29(4), pp. 1205-34.

Kaplow, Louis. "Human Capital under an Ideal Income Tax." Virginia Law Review, October 1994, 80(7), pp. 1477-514.

58(3), pp. 469-77.

. “A Note on Subsidizing Gifts." Journal of Public Economics, November 1995,

- 'On the Divergence Between 'Ideal' and Conventional Income-Tax Treatment of Human Capital." American Economic Association Papers and Proceedings, May 1996a, 86(2), pp. 347-52.

. "Optimal Distribution and the Family." Scandinavian Journal of Economics, March 1996b, 98(1), pp. 75-92.

- "The Optimal Supply of Public Goods and the Distortionary Cost of Taxation." National Tax Journal, December 1996c, 49(4), pp. 513-33.

- "Tax Policy and Gifts.” American Economic Association Papers and Proceedings, May 1998, 88(2), pp. 283-88.

and Shavell, Steven. "Any Non-Individualistic Social Welfare Function Violates the Pareto Principle.” NBER Working Paper No. 7051, March 1999. 
Kopczuk, Wojciech and Slemrod, Joel. "The Impact of the Estate Tax on the Wealth Accumulation and Avoidance Behavior of Donors," in this volume, 2000.

Kotlikoff, Laurence J. and Spivak, Avia. "The Family as an Incomplete Annuities Market." Journal of Political Economy, April 1981, 89(2), pp. 372-91.

Laibson, David I., Repetto, Andrea, and Tobacman, Jeremy. "Self-Control and Saving for Retirement." Brookings Papers on Economic Activity, 1998, pp. 91-172.

Laitner, John. "Simulating the Effects on Inequality and Wealth Accumulation of Eliminating the Federal Gift and Estate Tax," in this volume, 2000.

Lucas, Robert E., Jr., and Stark, Oded. "Motivations to Remit: Evidence from Botswana." Journal of Political Economy, October 1985, 93(5), pp. 901-18.

Masson, André, and Pestieau, Pierre. "Bequest Motives and Models of Inheritance: A Survey of the Literature, “ in Erreygers and Vandevelde (1997), pp. 54-88.

McCaffery, Edward J. "The Uneasy Case for Wealth Transfer Taxation." Yale Law Journal, November 1994, 104(2), pp. 283-365.

Munnell, Alicia H. "Wealth Transfer Taxation: The Relative Role for Estate and Income Taxes." New England Economic Review, November/December 1988, pp. 3-28.

Ng, Yew-Kwang. “Quasi-Pareto Social Improvements.” American Economic Review, December 1984, 74(5), pp. 1033-50.

Poterba, James. "Estate and Gift Taxes and Incentives for Inter Vivos Giving." NBER Working Paper No. 6842, December 1998; Journal of Public Economics (forthcoming).

and Weisbenner, Scott. "The Distributional Burden of Taxing Estates and Unrealized Capital Gains at the Time of Death," in this volume, 2000.

Repetti, James. "The Case for the Estate and Gift Tax.” Tax Notes, March 13, 2000, pp. 1493510.

Schmalbeck, Richard. "Avoiding Federal Wealth Transfer Taxes," in this volume, 2000.

Shavell, Steven. "A Note on Efficiency vs. Distributional Equity in Legal Rulemaking: Should Distributional Equity Matter Given Optimal Income Taxation?" American Economic Association Papers and Proceedings, May 1981, 71(2), pp. 414-18.

Simons, Henry C. Personal Income Taxation. Chicago: University of Chicago Press, 1938.

Slemrod, Joel, and Yitzhaki, Shlomo. "Integrating Expenditure and Tax Decisions: The 
Marginal Cost of Funds and the Marginal Benefit of Projects, 2000 (mimeo).

Stark, Oded. Altruism and Beyond: An Economic Analysis of Transfers and Exchanges within Families and Groups. Cambridge: Cambridge University Press, 1995.

Stiglitz, Joseph E. "Notes on Estate Taxes, Redistribution, and the Concept of Balanced Growth Path Incidence.” Journal of Political Economy, April 1978, part 2, 86(2), pp. S13750 .

- "Pareto Efficient and Optimal Taxation in the New New Welfare Economics," in A.J. Auerbach and M. Feldstein, eds., Handbook of Public Economics, Vol. 2. Amsterdam: North-Holland, 1987, pp. 991-1042.

Tax Law Review. “Colloquium on Wealth Transfer Taxation.” Spring 1996, 51(3).

. "Symposium on Wealth Taxation." Forthcoming 2000, 53(3\&4).

Taubman, Paul. "The Role of the Family in the Formation of Offsprings' Earnings and Income Capacity," in P.L. Menchik, ed., Household and Family Economics. Boston: Kluwer Academic Publishers, 1996, pp. 5-40. 